
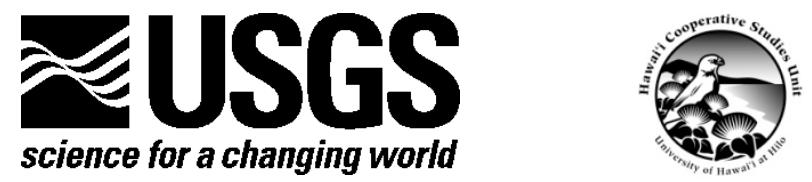

Prepared in cooperation with the Hawai'i Cooperative Studies Unit, University of Hawai'i at Hilo

\title{
Mapping Plant Species Ranges in the Hawaiian Islands- Developing a Methodology and Associated GIS Layers
}

By Jonathan P. Price, James D. Jacobi, Samuel M. Gon, III, Dwight Matsuwaki, Loyal Mehrhoff, Warren Wagner, Matthew Lucas, and Barbara Rowe

Open-File Report 2012-1192

U.S. Department of the Interior

U.S. Geological Survey 


\section{U.S. Department of the Interior \\ KEN SALAZAR, Secretary}

\section{U.S. Geological Survey \\ Marcia K. McNutt, Director}

U.S. Geological Survey, Reston, Virginia: 2012

For product and ordering information:

World Wide Web: http://www.usgs.gov/pubprod

Telephone: 1-888-ASK-USGS

For more information on the USGS—-the Federal source for science about the Earth, its natural and living resources, natural hazards, and the environment:

World Wide Web: http://www.usgs.gov

Telephone: 1-888-ASK-USGS

Suggested citation:

Price, J.P., Jacobi, J.D., Gon, S.M., III, Matsuwaki, D., Mehrhoff, L., Wagner, W., Lucas, M., and Rowe, B., 2012, Mapping plant species ranges in the Hawaiian Islands-Developing a methodology and associated GIS layers: U.S. Geological Survey Open-File Report 2012-1192, 34 p., 1 appendix (species table), 1,158 maps, available at http://pubs.usgs.gov/of/2012/1192/.

Any use of trade, product, or firm names is for descriptive purposes only and does not imply endorsement by the U.S. Government.

Although this report is in the public domain, permission must be secured from the individual copyright owners to reproduce any copyrighted material contained within this report. 


\section{Contents}

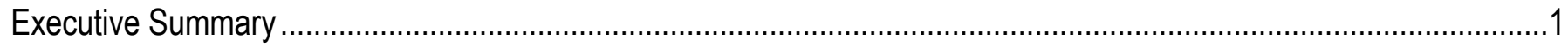

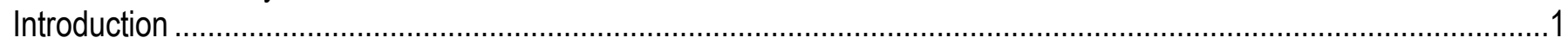

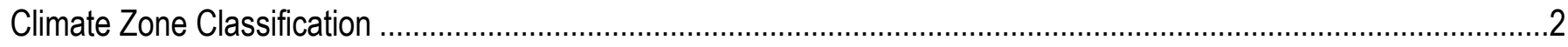

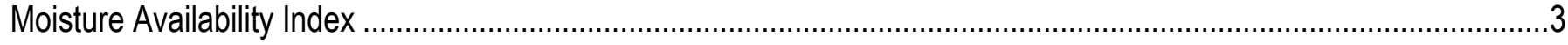

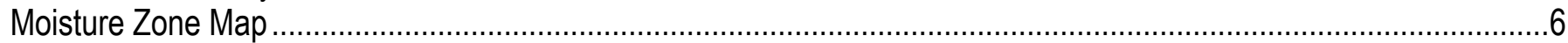

Adaptation of the Moisture-Zone Map to Species Distributions .........................................................................

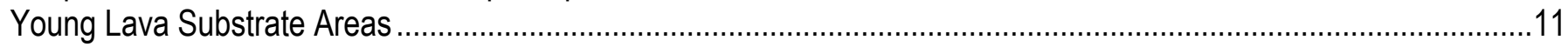

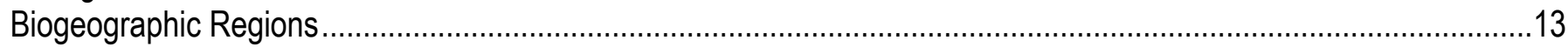

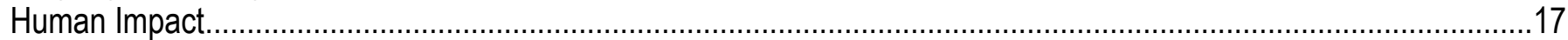

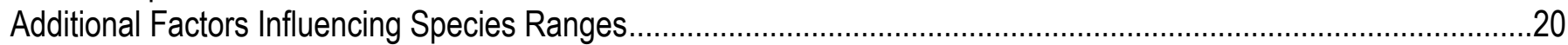

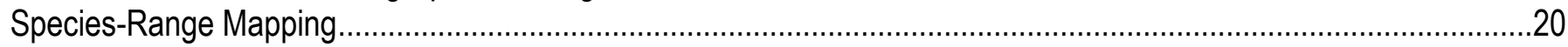

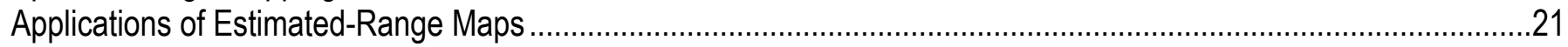

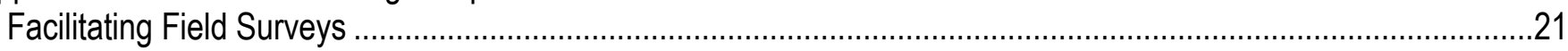

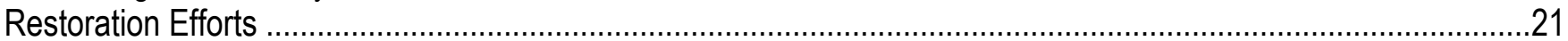

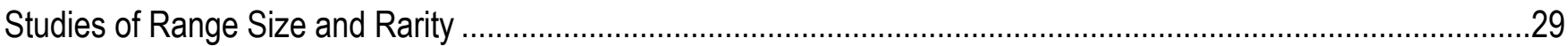

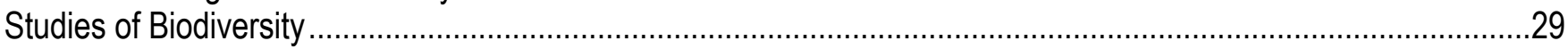

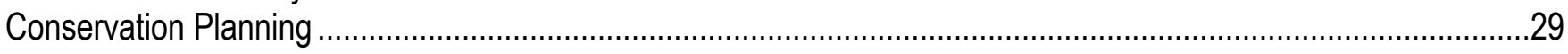

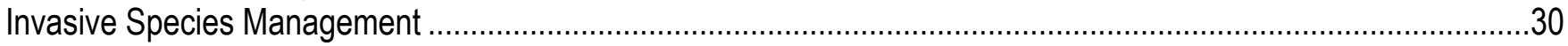

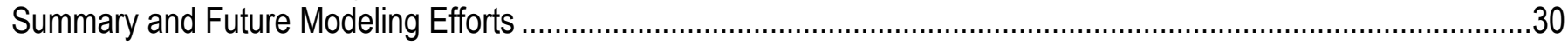

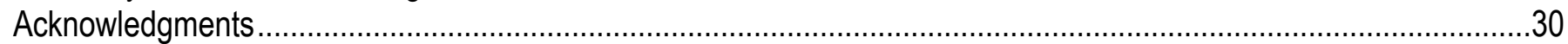

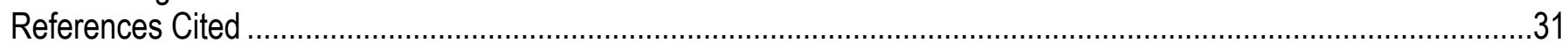

Appendix. Modeled Historic Range Maps for Hawaiian Vascular Plant Species..........................................................34

\section{Figures}

Figure 1. Elevational profile of potential evapotranspiration (PET). Modified from Bean and others (1994).............5

Figure 2. Comparison of estimated moisture availability index (MAl) surface with mapped vegetation from Jacobi (1989). Areas of coincidence: orange, Dry areas; green, Mesic areas; and Dark Blue, Wet areas. Areas of disagreement are colored according to which combination of designations that were given. Areas in gray were not covered by Jacobi's maps. Locations of rain gauges are shown for reference.

Figure 3. Approximate precipitation and elevation values used to define seven moisture zones used in this study. Zones are defined as follows: Zone 1, Arid; Zone 2, Very Dry; Zone 3, Moderately Dry; Zone 4, Seasonal Mesic; Zone 5, Moist Mesic; Zone 6, Moderately Wet; Zone 7, Very Wet. Sites in middle elevations may be in wetter moisture zones than areas that have comparable rainfall at higher or lower elevation, a function of depressed PET in middle elevations (fig. 1) that results in higher available moisture. Zonal boundaries only extend to precipitation-elevation combinations that exist; for example, no location exists above 2,300 $\mathrm{m}$ that receives more than $3,000 \mathrm{~mm}$ precipitation. Note that drier zones are more narrowly defined, in part, because areas that receive little rainfall are spatially extensive and, thus, more finely subdivided and, in part, because these are critical moisture thresholds that affect plant-species ranges.

Figure 4. Moisture zones on Nit'ihau, Kaua'i, O'ahu, Moloka'i, Lāna'i, Maui, and Kaho'olawe.................................9

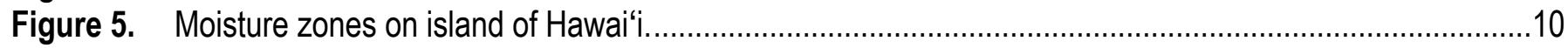

Figure 6. Areas of young lava substrates on Maui and Hawai i .................................................................14

Figure 7. Biogeographic regions on Ni'ihau, Kaua'i, O'ahu, Moloka'i, Lāna'i, Maui, and Kaho'olawe.....................15

Figure 8. Biogeographic regions on island of Hawai'i. ........................................................................... 16

Figure 9. Habitat-quality regions on Ni'ihau, Kaua'i, O'ahu, Moloka'i, Lāna'i, Maui and Kaho'olawe.......................18

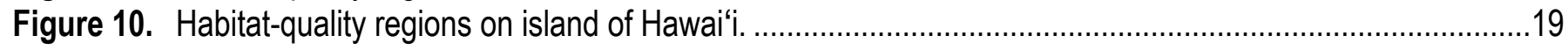


Figure 11. Habitat quality across modeled range of Sadleria cyatheoides on Ni'ihau, Kaua'i, O‘ahu, Moloka'i, Lāna'i, Maui, and Kaho'olawe. This species is known from Mesic and Wet habitats (moisture zones 4 through 7) across wide elevational range on many islands; it also extends into dryer areas in upper elevations on Maui and Hawai'i (Upland Dry Zone) but does not extend into drier habitats at lower elevations. Status of habitat for this species reflects commonly seen pattern for upland Wet/Mesic species in which much of estimated natural range remains in High- or Medium-quality habitat.

Figure 12. Habitat quality across modeled range of Sadleria cyatheoides on island of Hawai'i.

Figure 13. Habitat quality across modeled range of Erythrina sandwicensis on Ni'ihau, Kaua'i, O'ahu, Moloka'i, Lāna'i, Maui, and Kaho'olawe. This species is known from Arid to Seasonal Mesic habitats (moisture zones 1 through 4) at low elevations on many islands; it also extends into Moist Mesic areas (Zone 5) along coast but not inland. Status of habitat for this species is typical for species restricted to drier lowland areas where much of estimated natural range is Medium- or Low-quality habitat.

Figure 14. Habitat quality across modeled range of Erythrina sandwicensis on island of Hawai'i...........................26

Figure 15. Habitat quality across modeled range of Chamaesyce kuwaleana, restricted to O'ahu.........................27

Figure 16. Habitat quality across modeled range of Cyanea tritomantha, restricted to island of Hawai'i. This species is known from only a few biogeographic regions on one island, Hawai'i. Darker colors $(+)$ show areas where Cyanea tritomantha has been recorded; lighter colors (-) depict areas where it has not been recorded. Many species exhibit this pattern in which part of island may have appropriate habitat for a species, but that species has never been recorded there. In some cases, a species is naturally restricted; in other cases, there has been insufficient sampling in its potential habitat.

\section{Tables}

Table 1. Moisture availability index (MAI) values and approximate median annual precipitation (MAP) cutoff-zone values at different elevation boundaries of primary moisture zones.

Table 2. Climate zones in Hawaiian Islands, as adapted in plant-species database.

Table 3. Percent "sparse" or "very sparse" vegetation cover according to Hawai'i Gap Analysis Program land-cover map within each substrate-age-by-moisture-class combination. ..................................................... 13

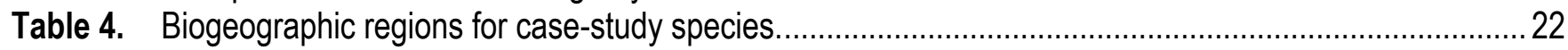

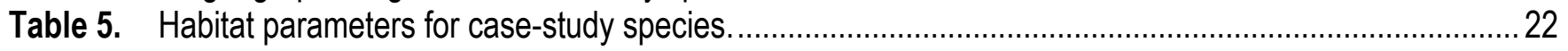




\title{
Mapping Plant Species Ranges in the Hawaiian Islands- Developing a Methodology and Associated GIS Layers
}

\author{
By Jonathan P. Price ${ }^{1}$, James D. Jacobi², Samuel M. Gon, III3 , Dwight Matsuwaki4 ${ }^{4}$ Loyal Mehrhoff ${ }^{5}$, Warren \\ Wagner ${ }^{6}$, Matthew Lucas ${ }^{1}$, and Barbara Rowe ${ }^{1}$
}

\section{Executive Summary}

This report documents a methodology for projecting the geographic ranges of plant species in the Hawaiian Islands. The methodology consists primarily of the creation of several geographic information system (GIS) data layers depicting attributes related to the geographic ranges of plant species. The most important spatial-data layer generated here is an objectively defined classification of climate as it pertains to the distribution of plant species. By examining previous zonal-vegetation classifications in light of spatially detailed climate data, broad zones of climate relevant to contemporary concepts of vegetation in the Hawaiian Islands can be explicitly defined. Other spatial-data layers presented here include the following: substrate age, as large areas of the island of Hawai' $i$, in particular, are covered by very young lava flows inimical to the growth of many plant species; biogeographic regions of the larger islands that are composites of multiple volcanoes, as many of their species are restricted to a given topographically isolated mountain or a specified group of them; and human impact, which can reduce the range of many species relative to where they formerly were found. Other factors influencing the geographic ranges of species that are discussed here but not developed further, owing to limitations in rendering them spatially, include topography, soils, and disturbance. A method is described for analyzing these layers in a GIS, in conjunction with a database of species distributions, to project the ranges of plant species, which include both the potential range prior to human disturbance and the projected present range. Examples of range maps for several species are given as case studies that demonstrate different spatial characteristics of range. Several potential applications of species-range maps are discussed, including facilitating field surveys, informing restoration efforts, studying range size and rarity, studying biodiversity, managing invasive species, and planning of conservation efforts.

\section{Introduction}

The Hawaiian Islands are home to nearly 1,200 native species of vascular plants, a large proportion of which either are listed as endangered, are candidates for such a listing, or are species of concern (U.S. Fish and Wildlife Service, 2012). A majority of these are restricted to a single island or are limited by habitat (Price, 2004); however, nonnative species now outnumber native species (Wagner and others, 1990; Wagner and Herbst, 1999), and many nonnative species are invasive threats to native ecosystems (Cuddihy and Stone, 1990; Staples and Cowie, 2001). The ranges of many native species have been summarized in their taxonomic descriptions (especially those by Wagner and others, 1990). Species that are important components of forest canopies have been mapped using combinations of

\footnotetext{
${ }^{1}$ University of Hawai'i, Hilo

${ }^{2}$ U.S. Geological Survey

3 The Nature Conservancy of Hawai' $i$

${ }^{4}$ Hawai i Biodiversity and Mapping Program, University of Hawai i, Honolulu

${ }^{5}$ U.S. Fish and Wildlife Service

${ }^{6}$ National Museum of Natural History, Smithsonian Institution
} 
fieldwork and aerial photography (Jacobi, 1989). Still other species, especially rare ones, have had specific locations mapped, most notably by the Hawai' $i$ Natural Heritage Program (now the Hawai' $i$ Biodiversity and Mapping Program) and the U.S. Fish and Wildlife Service; however, no single schema as yet exists for estimating geographic ranges that can be applied to all vascular plant species.

The most obvious approach to determining the geographic range of a given species would be to simply map its known locations; however, any mapping effort that is limited to documenting where species have been reliably recorded may prove problematic in several ways. First, widespread species are found at far too many locations to record them all, and, thus, only a subset of locations can be recorded with a reasonable effort. On the other hand, many rare species are known only from very scattered locations, and, thus, it would be difficult to assess their distributions in poorly explored areas. Finally, historically known locations may not fully represent where a species lived prior to widespread human disturbance. If the full natural range of a given species could be assessed, that assessment might offer important clues as to the ecological context in which a species evolved, as well as provide a credible basis for its potential restoration at a site. Therefore, an approach applicable to all species would use reasonable amounts of data for each species in order to extrapolate its geographic range in the broadest sense possible.

This report describes a methodology for projecting the geographic ranges of plant species in the Hawaiian Islands. The methodology primarily consists of the creation of several GIS data layers that depict attributes related to the geographic ranges of plant species. These layers include (1) climate zones, (2) young lava-substrate areas, (3) biogeographic regions, and (4) degrees of human impact. A specially constructed database then relates species locations to these GIS layers, leading to estimations of a species' potential geographic range.

The most important spatial-data layer described here is an objectively defined classification of climate as it pertains to the distribution of plant species. By examining previous zonal-vegetation classifications in light of spatially detailed climate data, broad zones of climate relevant to contemporary concepts of vegetation in the Hawaiian Islands are explicitly defined. A second spatial-data layer defines substrate age, as large areas of the island of Hawai' $i$, in particular, are covered by very young lava flows, which are inimical to the growth of many plant species. The third spatial-data layer divides larger islands, which are composites of multiple volcanoes, into definable biogeographic regions, as many species are restricted to a given topographically isolated mountain or a specified group of them. A final spatial-data layer depicts human impact, which can reduce the range of many species relative to where they formerly were found. Several other factors that influence the geographic ranges of species, including topography, soils, and disturbance, are discussed here but not developed further, owing to limitations in rendering them spatially.

\section{Climate Zone Classification}

Climate in the Hawaiian Islands is extremely variable: precipitation ranges from $250 \mathrm{~mm}$ to over $10,000 \mathrm{~mm}$, and temperature regimes range from tropical to alpine (Giambelluca and Schroeder, 1998). Hawaiian vegetation has been described in terms of climate since the first botanical explorations after European contact. Hillebrand (1888) divided vegetation into four elevation zones but described the variation of their breadth as depending on whether they are on windward (wet) or leeward (dry) slopes. A more detailed vegetation description by Rock (1913) similarly defined vegetation according to elevation and windward (wet) versus leeward (dry) aspects, in addition to including descriptions of major component species. In the first of these vegetation classifications to include potential vegetation maps, Ripperton and Hosaka (1942) used the dominance of characteristic native and nonnative species to define several major vegetation zones. In the most recent comprehensive vegetation classification, Gagné and Cuddihy (1990) not only considered different moisture and elevation zones but defined them somewhat explicitly; although it did not include a vegetation map, its exhaustive descriptions of 
different sites throughout the state permit many areas to be attributed to a give vegetation type. A series of vegetation maps by Jacobi (1989) served as a basis for the Gagné and Cuddihy (1990) classification; using a combination of extensive fieldwork from the Hawaiian Forest Bird Survey (HFBS) and aerial photographs, these maps attribute finely resolved areas to detailed vegetation types according to moisture zone, dominant cover, stature, and understory composition. The maps, however, primarily cover upland areas, particularly areas that include forest bird habitat, as these were the areas surveyed extensively by the HFBS. In addition, the maps only cover the islands of Lāna ' $i$, Moloka' $i$, Maui, and Hawai'i. A map by Gon and others (1998) that depicted potential vegetation also attempted to incorporate other influences in addition to climate, such as substrate, topography, and hydrography, for a generalized vegetation map for all islands, and these latter three vegetation classifications are used, and built upon, here.

The first step in generating a comprehensive map of climate zones is to rectify the functional definition of each zone with the perception of these on the ground. To do this, a median annual precipitation (MAP) map by Giambelluca and others (1986) was employed. This map, which consisted of isohyet lines, was available in digital form from the State of Hawai'i. From this map a continuous surface (with values for each 30-m-square cell in a grid) was interpolated using ArcInfo's TopoGrid command (Environmental Systems Research Institute, 2005), which accommodates line-data input, unlike other interpolation functions that require point-data input. Using this new MAP surface, a preliminary assessment was conducted of the agreement between Gagné and Cuddihy's (1990) moisture classes with maps created by Gon and others (1998) and Jacobi (1989). Initially, Gagné and Cuddihy defined the Dry Zone as being less than 1,200 mm annual rainfall; the Mesic Zone, between 1,200 and 2,500 $\mathrm{mm}$ annual rainfall; and the Wet Zone, greater than 2,500 $\mathrm{mm}$ annual rainfall; however, they did add itemized exceptions to these as a function of substrate or other influences in sections on individual types. This study depicts the mean annual precipitation (MAP) surface as the primary break points (1,200 $\mathrm{mm}$ for the Dry-Mesic boundary; 2,500 $\mathrm{mm}$ for the Mesic-Wet boundary), producing a map of the three moisture zones according to precipitation. When comparing this precipitation-based moisturezone map to other vegetation maps, a number of disparities were evident. Most notable was the fact that many areas that are considered Mesic on vegetation maps (Jacobi, 1989; Gon and others, 1998), such as the south slope of Haleakalā on Maui and the Kōke'e region on Kaua'i, receive somewhat less than $1,200 \mathrm{~mm}$ of precipitation annually.

\section{Moisture Availability Index}

A more detailed approach to the nature of moisture availability in different climates (Thornthwaite, 1948) assessed moisture availability as a function of annual precipitation and also potential evapotranspiration (PET), which represents the moisture demand of the atmosphere as a function of temperature and humidity and is strongly driven by the amount of incoming solar radiation. Bean and others (1994) found that middle elevations in the Hawaiian Islands exhibited lower PET values because they lie within the cloud belt and, thus, are high enough in elevation to have lower temperatures than sea level but not so high as to exceed the trade-wind inversion, above which clouds generally do not form and insolation is comparatively high (Giambelluca and Schroeder, 1998). It also is highly likely that strong variation in PET values exist, depending on aspect to prevailing trade winds and local topographic effects that influence cloud cover; however, at present there are insufficient PET data to map this variation in any detail.

Juvik and others (1978) considered a function of moisture inputs (through precipitation) and moisture demands (through evapotranspiration) in order to determine the major components of water balance. Thus, they subtracted PET values from MAP values to determine areas of potential moisture surplus and deficit on the island of Hawai' $i$. Another study by Juvik and Tango (2003) established a more detailed profile of precipitation, including fog-drip inputs, and PET values to consider moisture 
availability on the leeward side of the island of Hawai'i. Following a similar methodology, this study considered the difference between MAP and PET values (calculated as MAP minus PET). The resulting moisture availability index (MAI) better reflects variation in available moisture than precipitation alone and was used as a primary framework to compare with vegetation maps. Breakpoints were chosen in the MAI values that best fit the concepts of the Dry, Mesic, and Wet vegetation zones in Jacobi's (1989) maps. A breakpoint was chosen between Dry and Mesic that corresponds to the often-cited classification by Holdridge (1967), in which tropical dry forest climate is defined by those areas where annual PET values exceed MAP values (where MAI $<0$ ). A breakpoint was chosen between Mesic and Wet that approximates the value given by Gagné and Cuddihy (1990); although they defined this breakpoint at 2,500 mm MAP, the breakpoint was set at the MAI value where 2,500 $\mathrm{mm}$ of rainfall is received at $1,000 \mathrm{~m}$ elevation (where MAI=1,661 mm). Table 1 gives the moisture-balance values and the precipitation cutoffs at different elevations.

Table 1. Moisture availability index (MAI) values and approximate median annual precipitation (MAP) cutoff-zone values at different elevation boundaries of primary moisture zones.

[Note that Dry-Mesic boundary is where MAP value is equal to potential evapotranspiration (PET) value (MAI=0). Precipitation cutoffs are given for several elevations. For any given moisture-zone boundary, lowest precipitation-cutoff value is at 1,000 $\mathrm{m}$ where PET is lowest. At lower or higher elevations, more precipitation is needed to balance out higher PET values there. Cutoff values for Dry-Mesic and Mesic-Wet boundaries are not given above 2,500 m elevation because all areas higher than that are within Dry Zone]

\begin{tabular}{lccccccc}
\hline $\begin{array}{c}\text { Moisture-zone } \\
\text { boundary }\end{array}$ & $\begin{array}{c}\text { MAl value } \\
(\mathbf{m m})\end{array}$ & $\begin{array}{c}\text { MAP value } \\
(\mathbf{m m}) \text { at } \\
\mathbf{0 ~} \mathbf{m}\end{array}$ & $\begin{array}{c}\text { MAP value } \\
(\mathbf{m m}) \text { at } \\
\mathbf{5 0 0} \mathbf{m}\end{array}$ & $\begin{array}{c}\text { MAP value } \\
(\mathbf{m m}) \text { at } \\
\mathbf{1 , 0 0 0 ~} \mathbf{m}\end{array}$ & $\begin{array}{c}\text { MAP value } \\
(\mathbf{m m}) \text { at } \\
\mathbf{1 , 5 0 0 ~} \mathbf{m}\end{array}$ & $\begin{array}{c}\text { MAP value } \\
(\mathbf{m m}) \text { at }\end{array}$ & $\begin{array}{c}\text { MAP value } \\
(\mathbf{m m}) \text { at }\end{array}$ \\
\hline Dry-Mesic & 0 & 1,300 & 1,000 & 800 & 900 & 1,050 & 1,500 \\
Mesic-Wet & 1,661 & 3,000 & 2,700 & 2,500 & 2,600 & 2,750 & 3,200 \\
\hline
\end{tabular}

Maps of estimated MAP and PET values were used to estimate MAI values statewide. To characterize PET values in different areas, a generalized profile was first derived using data from Bean and others (1994) that reflects the somewhat lower PET values at middle elevations (fig. 1). Then a statewide digital elevation model (DEM) (standardized to a 30-m cell size and a 1-m vertical resolution) was used to attribute PET values to areas at different elevations. The resulting surface represents an estimate of PET across all islands. In reality, it is certain that PET values vary by island, by aspect with respect to trade winds, and by other factors; however, at present not enough measurements of PET values have been made in different areas to be able to map this spatial variability in detail. Nonetheless, the projected PET surface represents a rough approximation of spatial variation (with respect to elevation) and can be combined with precipitation values to better represent available moisture. By subtracting the estimated PET value from the estimated MAP value for each grid cell, a surface that estimates MAI statewide was generated. Then, using the MAI-value breakpoints defined above, the estimated MAI surface (representing MAP minus PET values) was partitioned into the three primary moisture zones (Dry, Mesic, and Wet).

The partitioned MAI surface was assessed using Jacobi's (1989) map, as it represents a vegetation classification derived from field observations of vegetation characteristics and is largely independent of climate. Jacobi's (1989) map was converted into a 30-m grid coverage of Dry, Mesic, and Wet Zones and then compared to the zones depicted in the estimated MAI surface. The MAI surface agreed with Jacobi's map in 66 percent of grid cells; was drier in 10 percent of grid cells; and was wetter in 23 percent of grid cells. Areas classified as unvegetated by Jacobi (1989) were not considered, as these represented lava flows across various moisture zones. Figure 2 shows a portion of Moloka' $i$ as an example of how the maps differ. 


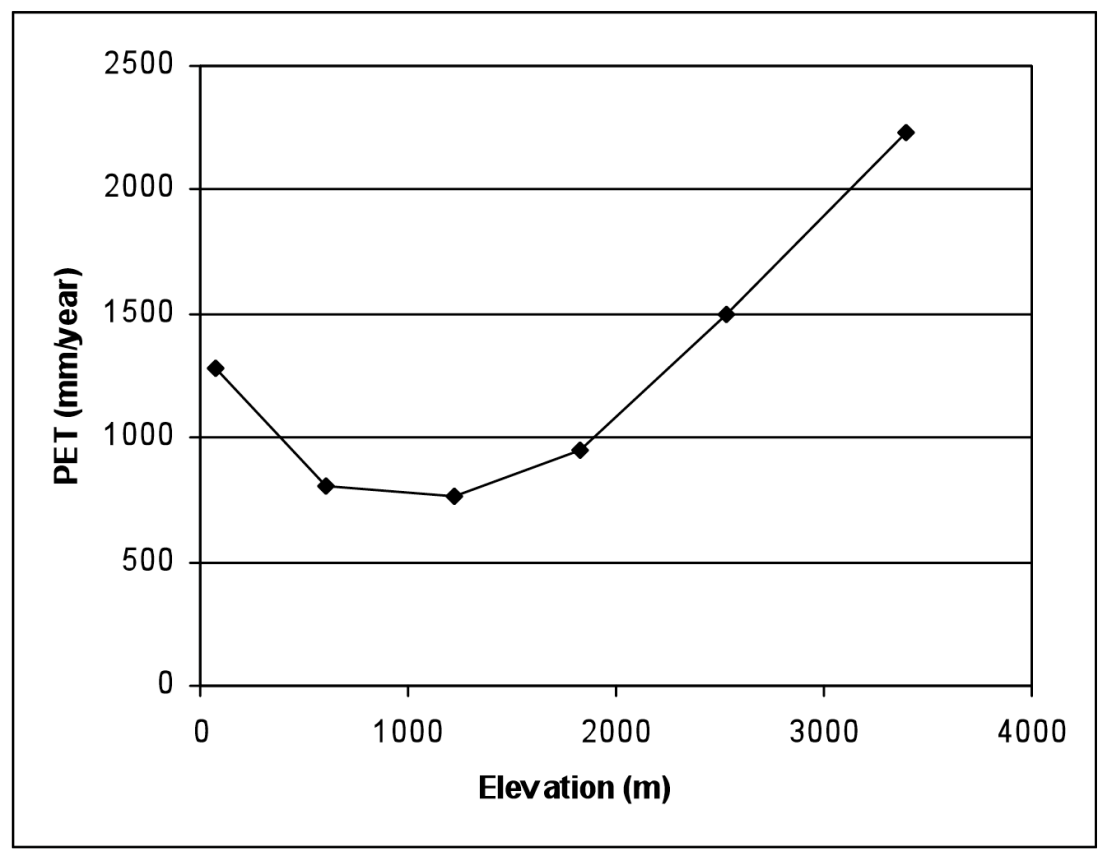

Figure 1. Elevational profile of potential evapotranspiration (PET). Modified from Bean and others (1994).

Several possible reasons may explain why a given location is classified differently according to the MAI surface than it is in Jacobi's (1989) map. First, the MAI surface is derived from interpolated precipitation maps that are fairly generalized and that, in some cases, may differ somewhat from actual local climate-station data. In other cases, comparatively few climate stations exist, and interpolated precipitation values may not accurately reflect actual MAP values. This absence of climate data is particularly acute for remote areas; however, many such areas lie within the regions covered by Jacobi's (1989) map because they represent large tracts of native vegetation. Thus, where climate data is clearly lacking, Jacobi's vegetation map may more accurately represent available moisture than the estimated MAI surface.

In other areas that have good climate data, however, Jacobi’s (1989) map differs markedly from the estimated MAI surface. Such discrepancies typically are due to at least one of two situations. The first situation involves areas of relatively young lava substrates. One of the criteria that indicate Wet vegetation is the relative cover of tree ferns; however, even in areas that receive ample precipitation, relatively young lava substrates largely preclude their growth, and so the area is classified as Mesic in Jacobi's map. Similarly, a more open canopy or shrub cover is an indicator of Dry vegetation in many areas of Jacobi's map, even though these areas receive sufficient rainfall to classify as Mesic; again, however, this typically involves areas of young lava substrates. Because of this, young substrate areas are treated in a separate section for this study. The second situation where Jacobi's (1989) map classifies areas as drier than the estimated MAI surface are areas of habitat degradation, particularly by introduced ungulates. For example, areas that are Wet according to the estimated MAI surface but where cattle grazing has disturbed the understory and reduced the cover of tree ferns are classified as Mesic in Jacobi's map. Similarly, areas that are open or that even have no tree canopy and considerable cover by pasture grass are considered Dry in Jacobi's classification, despite reliable climate data that places them in the Mesic or even Wet climate zone. 


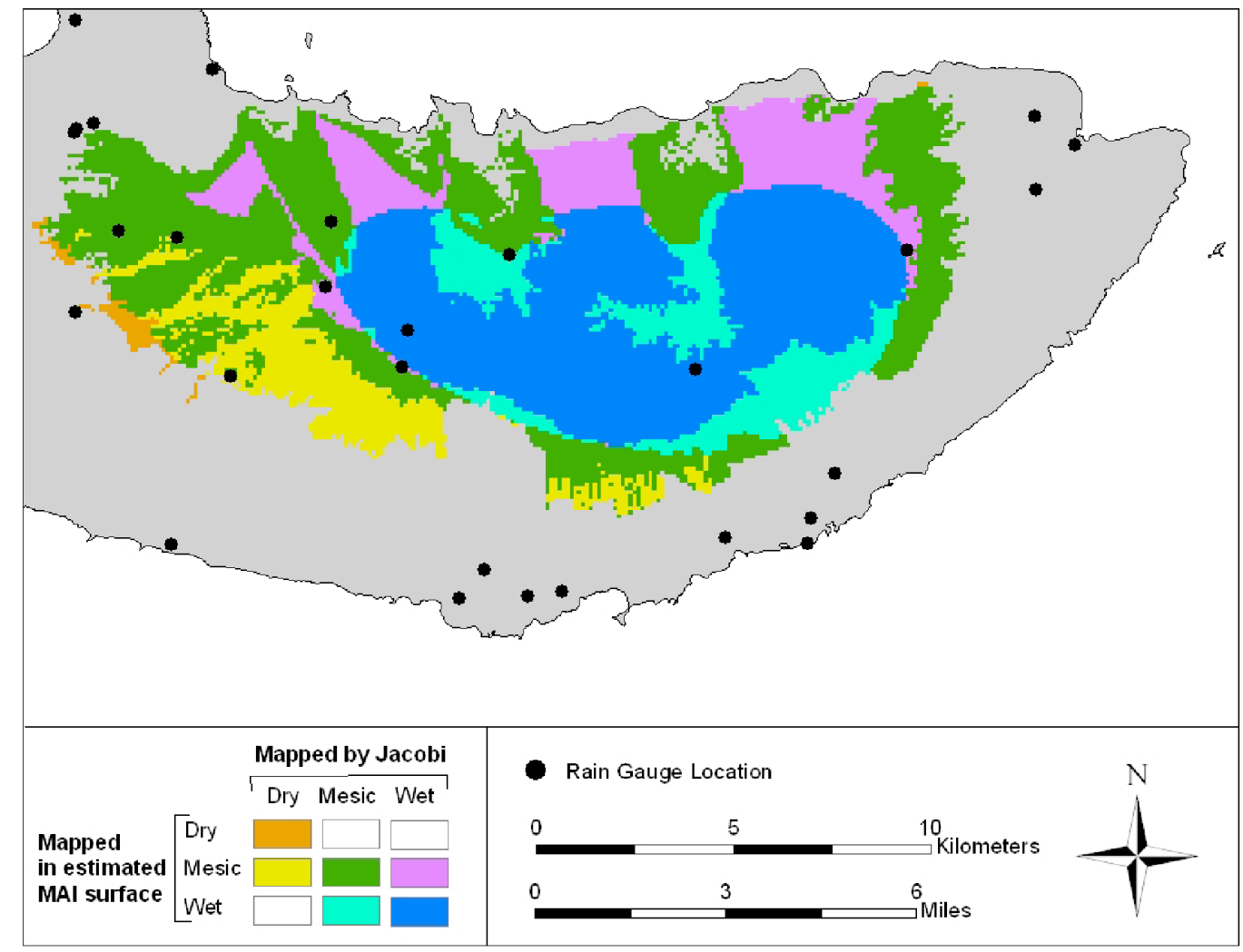

Figure 2. Comparison of estimated moisture availability index (MAI) surface with mapped vegetation from Jacobi (1989). Areas of coincidence: orange, Dry areas; green, Mesic areas; and Dark Blue, Wet areas. Areas of disagreement are colored according to which combination of designations that were given. Areas in gray were not covered by Jacobi's maps. Locations of rain gauges are shown for reference.

In order to rectify differences between Jacobi's map and the estimated MAI surface, major areas where the two differ were assessed along with local climate data, when available. In areas outside those covered by Jacobi's maps, designations from the map by Gon and others (1998) and descriptions in Gagné and Cuddihy (1990), as well as incidental observations, were used. In many instances, data from individual climate stations provide a more reliable local estimate of MAI than that from the estimated MAI surface, which can be inaccurate owing to the generalized nature of the MAP- and PET-value maps.

\section{Moisture Zone Map}

After resolving differences between the estimated MAI surface and other sources, a new moisture-zone map was created on which each of the three primary moisture zones was further subdivided, and each new zone was numbered from 1 to 7 , from driest to wettest:

- The Wet Zone was divided into two zones: areas that have an MAI value greater than 3,161 (1,500 $\mathrm{mm}$ above the Wet-Mesic boundary) constitute the Very Wet Zone (Zone 7), and areas that have an MAI value less than 3,161 constitute the Moderately Wet Zone (Zone 6). 
- The Mesic Zone was divided into two zones: areas that have an MAI value greater than 861 constitute the Moist Mesic Zone (Zone 5), and areas that have an MAI value less than 861 constitute the Seasonal Mesic Zone (Zone 4).

- The Dry Zone, because it includes far more area than the Wet or Mesic Zones, was subdivided into three new zones: areas that have an MAI value between 0 and -389 constitute the Moderately Dry Zone (Zone 3); areas hat have an MAI value between -389 and -689 constitute the Very Dry Zone (Zone 2); and areas that have an MAI value less than -689 constitute the Arid Zone (Zone 1).

The combinations of MAP values and elevation estimated to place a site within a given zone are depicted graphically in figure 3.

To produce the new moisture-zone map, lines were digitized according to whichever data source was considered the most reliable for a given region. In areas where the estimated MAI surface is considered reliable (in other words, where climate data are reliable), boundaries between moisture zones were placed according to appropriate breakpoints in the MAI values. In areas where the estimated MAI surface was not reliable, other sources (for example, Jacobi, 1989; Gon and others, 1998) were used to demarcate zonal boundaries. Lines were drawn so as to be smooth and generalized (rather than depicting a false sense of precision by following sinuous boundaries demarcated by a given source) at a scale of 1:70,000. The result is a map of seven moisture zones, each representing a discrete zone of moisture availability for the main Hawaiian Islands (figs. 4, 5).

\section{Adaptation of the Moisture-Zone Map to Species Distributions}

The moisture-zone map was adapted to reflect patterns in species distributions. First, many species are known from several moisture zones but are restricted to areas near the coast; this is different from being restricted to low elevations because such species are frequently known at over $100 \mathrm{~m}$ elevation on sea cliffs but are not found at comparable elevations inland. Other species have more extensive distributions along the coast than they do inland. For example, Erythrina sandwicensis has been recorded in Zones 1 to 5 near the coast but is limited to Zones 1 to 4 inland. To depict this coastal zone on the habitat maps, a buffer of $500 \mathrm{~m}$ was generated from the coastline; those areas falling within the buffer are classified as coastal, and they too are divided among the seven climate zones. This distance was chosen because, although the coastal zone certainly varies in width and in the influences of salt spray, wind, and floating water table (the Ghyben-Herzberg effect), the area within $500 \mathrm{~m}$ likely contains the vast majority of sites with these conditions.

Another adaptation of the moisture-zone classification is a special consideration of the three driest zones (1 to 3) at higher elevations. These zones are restricted to elevations below 1,000 $\mathrm{m}$ on all islands except on east Maui and on Hawai 'i, where extensive areas that have drier climates are present at higher elevations. These upland Dry regions are largely separate from lowland Dry regions: on Maui, they are entirely disjunct, and on the island of Hawai' $i$, a comparatively small amount of area at middle elevations connects upland and lowland Dry regions. In many cases, species that are otherwise restricted to the Mesic and Wet Zones inhabit one of the three Dry Zones at higher elevations on Maui and Hawai' $i$. This may reflect the fact that these higher elevation areas experience lower daytime high temperatures and, therefore, lower heat stress than lowland Dry regions. This may also be due to moisture input from fog at higher elevations, which may add critical moisture during otherwise dry summer months (Juvik and Ekern, 1978; Juvik and Tango, 2003). However, these regions also have very poor precipitation records, owing to the large distances between climate stations. For example, the central plateau of Hawai' $i$ has only a few rain gages scattered along its margin, and none in its center. Therefore, although these dry upland regions can be considered climatically distinct from lower elevation dry regions, there is little confidence that boundaries among Zones 1, 2, and 3 are well defined. Records of native plant species also are somewhat limited in these areas, adding further 


\section{Moisture Zone Definition}

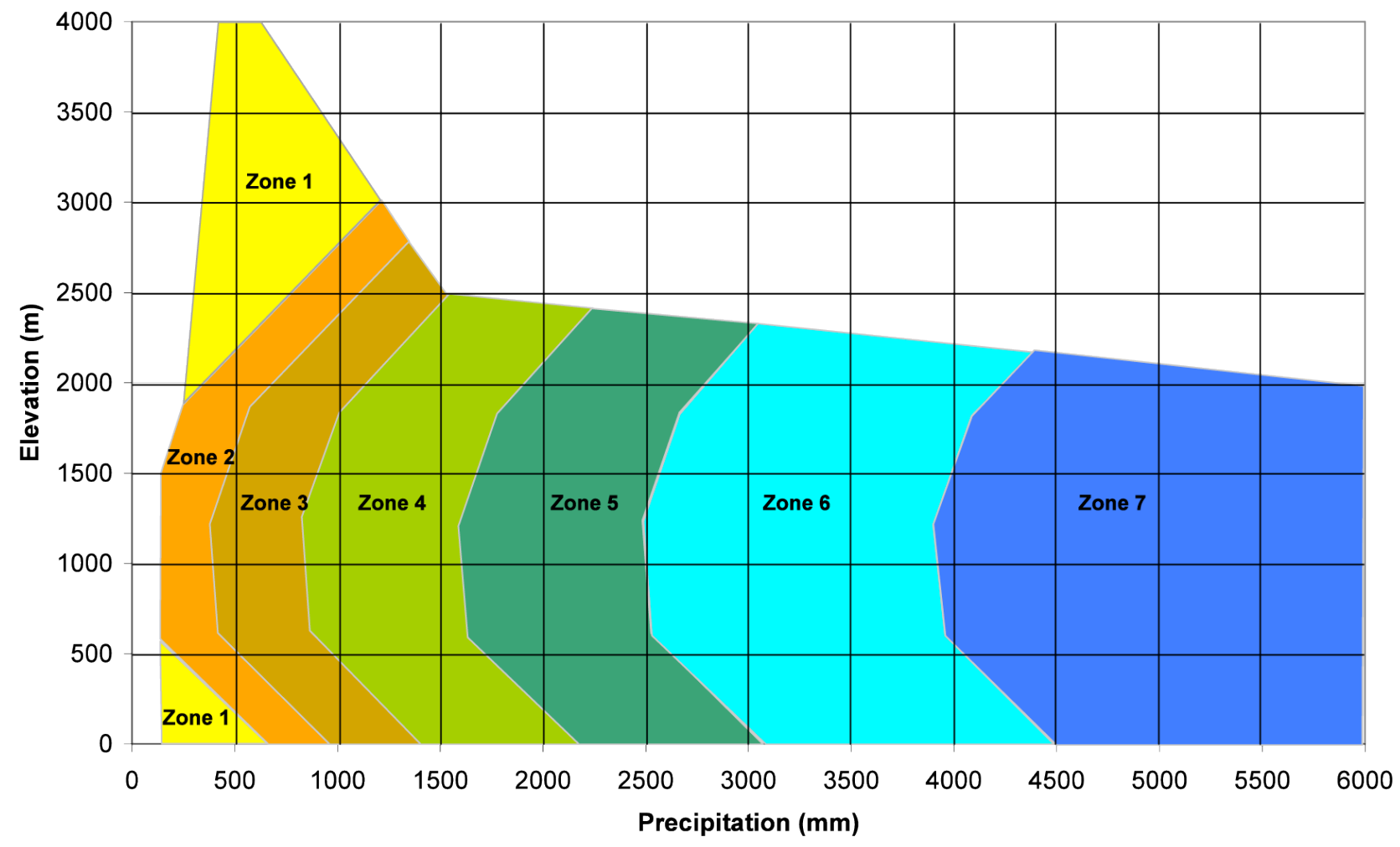

Figure 3. Approximate precipitation and elevation values used to define seven moisture zones used in this study. Zones are defined as follows: Zone 1, Arid; Zone 2, Very Dry; Zone 3, Moderately Dry; Zone 4, Seasonal Mesic; Zone 5, Moist Mesic; Zone 6, Moderately Wet; Zone 7, Very Wet. Sites in middle elevations may be in wetter moisture zones than areas that have comparable rainfall at higher or lower elevation, a function of depressed PET in middle elevations (fig. 1) that results in higher available moisture. Zonal boundaries only extend to precipitation-elevation combinations that exist; for example, no location exists above 2,300 $\mathrm{m}$ that receives more than $3,000 \mathrm{~mm}$ precipitation. Note that drier zones are more narrowly defined, in part, because areas that receive little rainfall are spatially extensive and, thus, more finely subdivided and, in part, because these are critical moisture thresholds that affect plant-species ranges. 


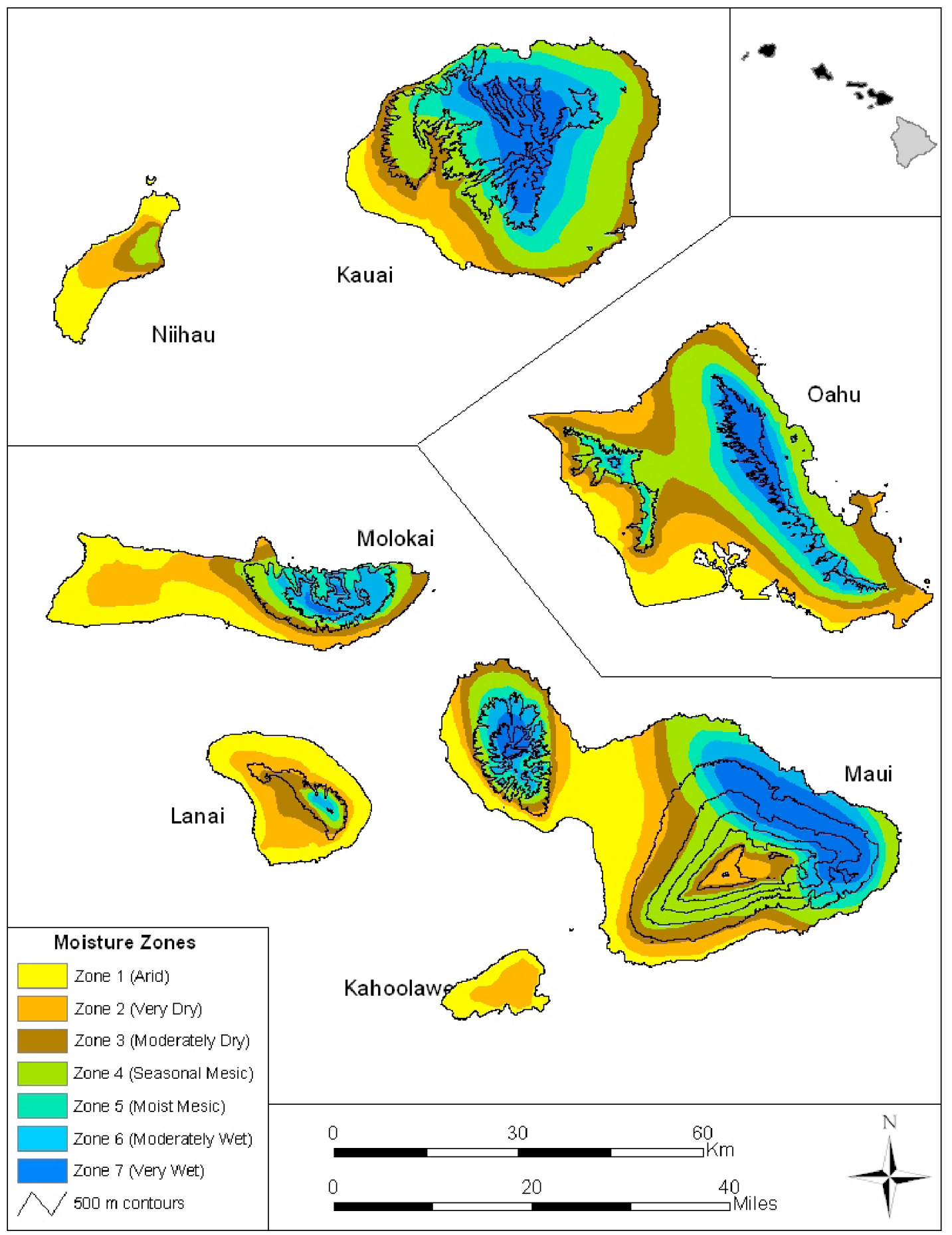

Figure 4. Moisture zones on Ni'ihau, Kaua‘i, O‘ahu, Moloka‘i, Lāna‘i, Maui, and Kaho‘olawe. 


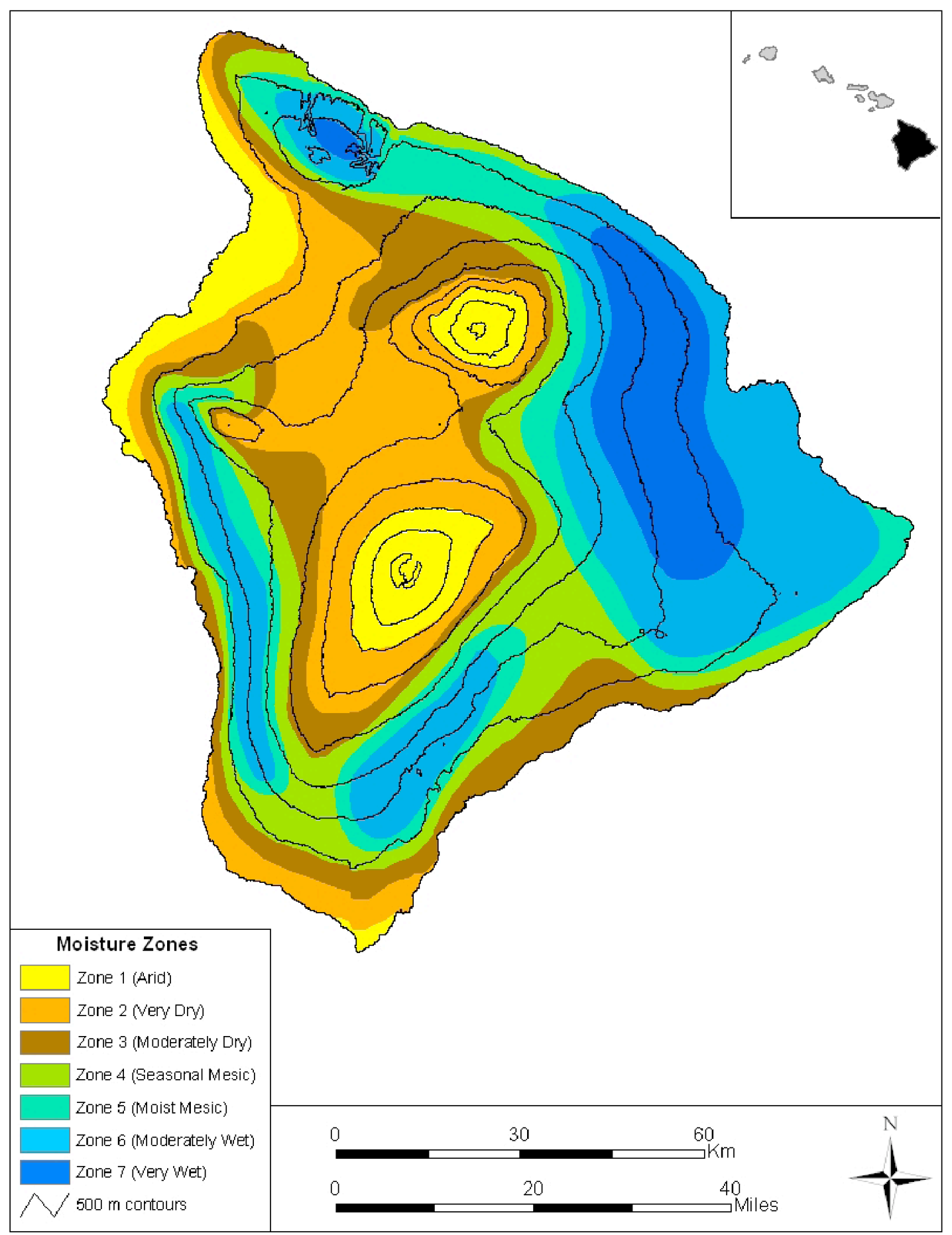

Figure 5. Moisture zones on island of Hawai'i. 
difficulty in the ability to confidently place species within a given moisture zone. For purposes of defining species ranges, Zones 1, 2, and 3 were, therefore, combined for areas above 1,250 $\mathrm{m}$. This new Upland Dry Zone is considered distinct from Zones 1 to 3 at lower elevations. The final set of zones used in the species database is presented in table 2.

Table 2. Climate zones in Hawaiian Islands, as adapted in plant-species database.

\begin{tabular}{lcl}
\hline \multicolumn{1}{c}{ Climate zone } & Moisture zones & \multicolumn{1}{c}{ Islands } \\
\hline Coastal - Arid & 1 & All islands \\
Coastal - Very Dry & 2 & All islands except Lāna'i \\
Coastal - Moderately Dry & 3 & All islands except Lāna'i and Kaho'olawe \\
Coastal - Seasonal Mesic & 4 & All islands except Lāna'i and Kaho'olawe \\
Coastal - Moist Mesic & 5 & Kaua'i, Moloka'i, Maui, and Hawai'i \\
Coastal - Moderately Wet & 6 & Moloka'i, Maui, and Hawai'i \\
Coastal - Very Wet & 7 & Maui only \\
Arid & 1 & All islands \\
Very Dry & 2 & All islands \\
Moderately Dry & 3 & All islands except Kaho'olawe \\
Seasonal Mesic & 4 & All islands except Kaho'olawe \\
Moist Mesic & 5 & All islands except Ni'ihau and Kaho'olawe \\
Moderately Wet & 6 & All islands except Ni'ihau and Kaho'olawe \\
Very Wet & 7 & Kaua'i, O'ahu, Moloka'i, Maui, and Hawai'i \\
Upland Dry & $1,2,3$ & Maui and Hawai'i only \\
\hline
\end{tabular}

\section{Young Lava Substrate Areas}

Young lava substrates impose several well-known influences on vegetation in the Hawaiian Islands. The unweathered nature of most volcanic substrates permits little soil formation and results in a high degree of drainage that retains less moisture than weathered substrates (Kitayama and others, 1995). In addition, younger soils are deficient in nutrients, particularly nitrogen (Crews and others, 1995). According to a study of several lava flows of varying age within the moderately wet climate zone (Kitayama and others, 1995), lava flows younger than 200 years restrict many species and, thus, support only very sparse vegetation. However, in drier climate regions, vegetation remains stunted on even moderately aged lava flows (Aplet and Vitousek, 1994). The pioneer vegetation associated with young lava substrates is likely inimical to the growth of many plant species that cannot tolerate such conditions; on the other hand, some species such as Rumex skottsbergii and Scaevola kilaueae appear to prefer this type of vegetation (Wagner and others, 1990).

Although many studies have chronicled the development of vegetation on lava flows within wet climates, comparatively little has been done in areas that have a drier climate. Stemmerman and Ihsle (1993) demonstrated that in Very Dry, Moderately Dry, and Seasonal Mesic areas (moisture Zones 2 to 4), vegetation shows marked changes in composition and dominance with increasing age. Most substrates 3,000 years or older support well-developed vegetation, as opposed to the pioneer vegetation on younger flows dominated by either sparse or small 'Ōhi'a (Metrosideros polymorpha). A study of litter production across sites receiving different amounts of rainfall (Austin, 2002) indicated that a site at 
Kanikuū Lava Flow, Hawai'i, which is within the Moderately Dry Zone (Zone 3) and has a substrate age of 2,800 years, shows characteristics of a pioneer community when compared to moister sites that have a similar substrate age. These characteristics include fewer species, low rates of litter production, low foliar-nitrogen concentration, and a dominance by 'Ohi'a (which does not dominate on older substrates in drier climate zones).

In summary, it appears that, in the wettest areas, young lava substrates support well-developed vegetation within perhaps as little as a few hundred years, whereas in drier areas the process may take as many as 3,000 years or more. An exception to this general pattern are the comparatively young, deep volcanic-ash substrates, which show species composition and soil characteristics comparable to very well developed substrates (Balakrishnan and Mueller-Dombois, 1983; Vitousek and others, 1983). To better resolve the general pattern, substrate characteristics were assessed in this study using both geologic and climatic GIS maps.

Geologic maps depicting lava-flow age are available for the islands of Hawai'i (Wolfe and Morris, 1996) and Maui (Sherrod and others, 2006). These maps classify lava age as one of the following seven categories: younger than 200 years; 200-750 years; 750-1,500 years; 1,500-3,000 years; 3,000-5,000 years; 5,000-10,000 years; and older than 10,000 years. Some substrates, however, notably alluvium, were not given an age designation, although in some cases they represent landslide deposits attributable to lava flows of known age. These areas were, therefore, classified according to the most likely source of parent material. Regardless of their actual age, areas that have deep ash substrate were reclassified into the oldest age class ( $>10,000$ years), owing to the unique characteristics of this substrate type. The geologic maps were converted to $30-\mathrm{m}$ grids that contain values representing the seven age classes. Then this age-class grid was combined with a 30-m grid of climatic moisture zones (defined earlier in this report) to determine the combination of age class and moisture zone at each given location.

In order to determine which age classes should be designated as young lava substrate for each given moisture zone, moisture zones and substrate ages were examined in the context of a land-cover classification; this land-cover grid, produced by the Hawai'i Gap Analysis Program (HIGAP), is based on LandSat Thematic Mapper satellite imagery and represents major structural vegetation types (Gon, 2006). Land-cover classes were then grouped according to those that were considered either unvegetated or vegetated with what is considered to be pioneer vegetation (including land-cover classes "Very Sparse Vegetation to Unvegetated" and "Sparse "Ōhi'a/Native Shrub"). For each moisture-zone-bysubstrate-age combination, the proportion of the area covered by sparse vegetation was examined. Areas in the arid zone that are associated with alpine habitats (that is, above 3,000 $\mathrm{m}$ elevation) were excluded, as these consist almost entirely of sparse vegetation, regardless of substrate age. Results are summarized in table 3 .

A clear trend exists where sparse vegetation makes up large proportions of areas that are young substrate age. In the wettest areas (Zones 6 and 7), no age class had a majority of its area covered by sparse vegetation; instead, areas within the two wettest zones that were on the youngest substrates $(<200$ years) tended to be covered in open 'Ōhi'a and Uluhe (Dicranopteris linearis), a mat-forming fern. Nonetheless, studies from areas with this moisture-substrate combination (Kitayama and others, 1995; Aplet and Vitousek, 1994) have indicated that species composition is limited. Starting with the Moist Mesic Zone (Zone 5), progressively older lava-substrate age classes are covered primarily (at least 75\%) by sparse vegetation. At the Arid end of the spectrum (Zone 1), all age classes younger than 3,000 years were covered at least 75 percent in sparse vegetation. The 3,000-to-5,000-year-old age class within the Arid Zone included nearly as high a proportion of its vegetation covered in sparse vegetation (73\%); however, much of this area is human modified (the Kailua-Kona region includes the city of Kailua, Hawai' $i$, and the resort areas to the north) and, thus, might have had a higher proportion of sparse vegetation originally. This pattern is generally in agreement with that of studies of individual sites where substrate development takes longer at drier sites. 
Table 3. Percent "sparse" or "very sparse" vegetation cover according to Hawai'i Gap Analysis Program land-cover map within each substrate-age-by-moisture-class combination.

[Age-by-moisture combinations that have more than $75 \%$ of their area being sparsely vegetated are designated as young substrates and are shown in bold. Areas within Zone 6 and 7 (Moderately Wet and Very Wet) and in the youngest substrate age class ( $<200$ years) are also considered young substrate areas because their vegetation is limited in species composition. In addition, areas within moisture Zone 1 (Arid) and in the 3,000-to-5,000-year-old substrate age class, although being only $73 \%$ covered in sparse vegetation, are also nominally included]

\begin{tabular}{lrrrrrrr}
\hline \multicolumn{1}{c}{ Age (in years) } & $\begin{array}{c}\text { Moisture } \\
\text { Zone 1 }\end{array}$ & $\begin{array}{c}\text { Moisture } \\
\text { Zone 2 }\end{array}$ & $\begin{array}{c}\text { Moisture } \\
\text { Zone 3 }\end{array}$ & $\begin{array}{c}\text { Moisture } \\
\text { Zone 4 }\end{array}$ & $\begin{array}{c}\text { Moisture } \\
\text { Zone 5 }\end{array}$ & $\begin{array}{c}\text { Moisture } \\
\text { Zone 6 }\end{array}$ & $\begin{array}{c}\text { Moisture } \\
\text { Zone 7 }\end{array}$ \\
\hline$<200$ & $\mathbf{9 4}$ & $\mathbf{9 9}$ & $\mathbf{9 8}$ & $\mathbf{9 5}$ & $\mathbf{7 6}$ & $\mathbf{5 8}$ & $\mathbf{7}$ \\
$200-750$ & $\mathbf{9 2}$ & $\mathbf{9 9}$ & $\mathbf{8 4}$ & $\mathbf{8 2}$ & 39 & 9 & 5 \\
$750-1.500$ & $\mathbf{6 3}$ & $\mathbf{9 6}$ & $\mathbf{7 5}$ & 58 & 17 & 3 & 0 \\
$1,500-3,000$ & $\mathbf{7 9}$ & $\mathbf{9 1}$ & 58 & 38 & 10 & 2 & 0 \\
$3,000-5,000$ & $\mathbf{7 3}$ & 67 & 29 & 20 & 4 & 1 & 0 \\
$5,000-10,000$ & 29 & 54 & 22 & 11 & 2 & 3 & 1 \\
$>10,000$ & 6 & 15 & 6 & 6 & 2 & 2 & 2 \\
\hline
\end{tabular}

Certain substrates were considered to be young lava, using the following moisture and age criteria: in the Moist Mesic through Wet moisture zones (Zones 5 to 7 ), substrates that are $<200$ years are considered young lava; in the Seasonal Mesic Zone (Zone 4), $<750$ years; in the Moderately Dry Zone (Zone 3) $<1,500$ years; in the Very Dry Zone (Zone 2), <3,000 years; and in the Arid Zone (Zone $1),<5,000$ years. These areas represent a large portion of the island of Hawai' $i$ and a limited portion of Maui, but they are not found on other islands (fig. 6). Although substrate age and climatic moisture are primary drivers of rates of succession, the designation given here should be considered as a general estimate of soil and vegetation development. Additional factors such as elevation or whether the substrate is ' $a$ 'a or pahoehoe lava may be of comparable importance in determining the ability of species to colonize lava flows. These additional factors will require further research.

\section{Biogeographic Regions}

By subdividing the Hawaiian Islands into distinct geographic regions, a species' potential habitat can be bracketed by those islands and by portions of islands on which the species has been recorded. Isolation of populations on different islands facilitates the evolution of distinct species that are restricted in their distribution (Carlquist, 1980; Wagner and Funk, 1995). Furthermore, some islands consist of more than one topographically distinct volcanic mountain, promoting further possibilities for geographic restriction. Consequently, over 40 percent of native Hawaiian flowering plant species are restricted to a single volcanic mountain (Price, 2004).

Following Price (2004), the islands of $\mathrm{O}^{\prime}$ ahu, Moloka' $\mathrm{i}$, and Maui were divided into two geographic regions, each corresponding to separate volcanic masses. The island of Hawai' $i$ was divided into its five constituent volcanic mountains (Kohala, Mauna Kea, Hualālai, Mauna Loa, and Kīlauea). In addition, Mauna Loa was subdivided into four additional subregions because it covers far more area than any other volcanic mountain, and also because its slopes include disjunct areas of certain climate zones. The subregions of Mauna Loa include the following: northwest, positioned between Hualālai and Mauna Kea; northeast, stretching from Mauna Kea south and including the Mauna Loa part of Hawai ' $\mathrm{i}$ Volcanoes National Park; southeast, stretching from the Hawai' $i$ Volcanoes National Park boundary to the Ka ${ }^{a} \overline{\mathrm{u}}-$ South Kona District boundary; and southwest Mauna Loa, stretching from the Ka ${ }^{6} \overline{\mathrm{u}}-$ South Kona District to Hualālai. To explicitly define each of these regions, GIS coverages (figs. 7, 8) were 


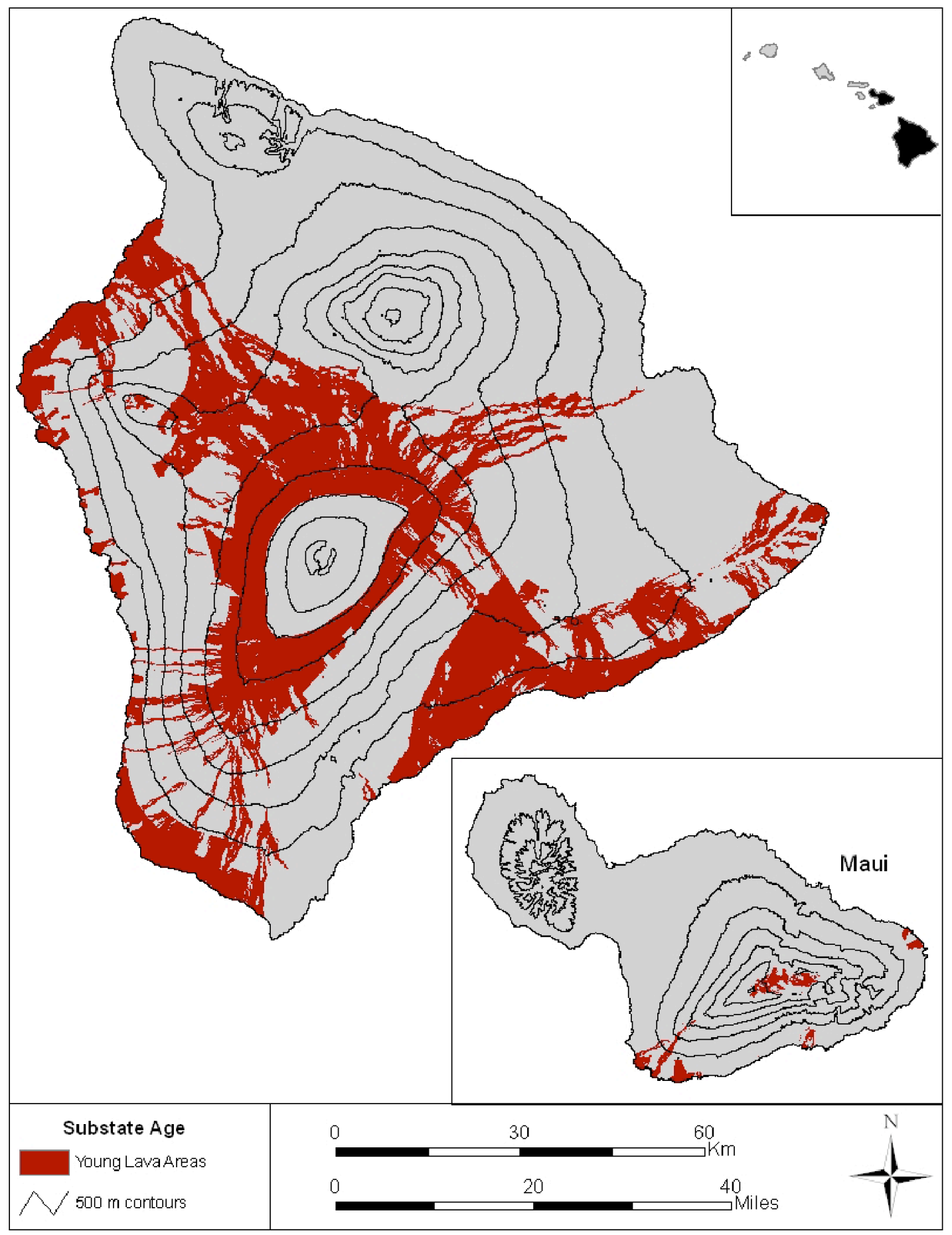

Figure 6. Areas of young lava substrates on Maui and Hawai'i. 


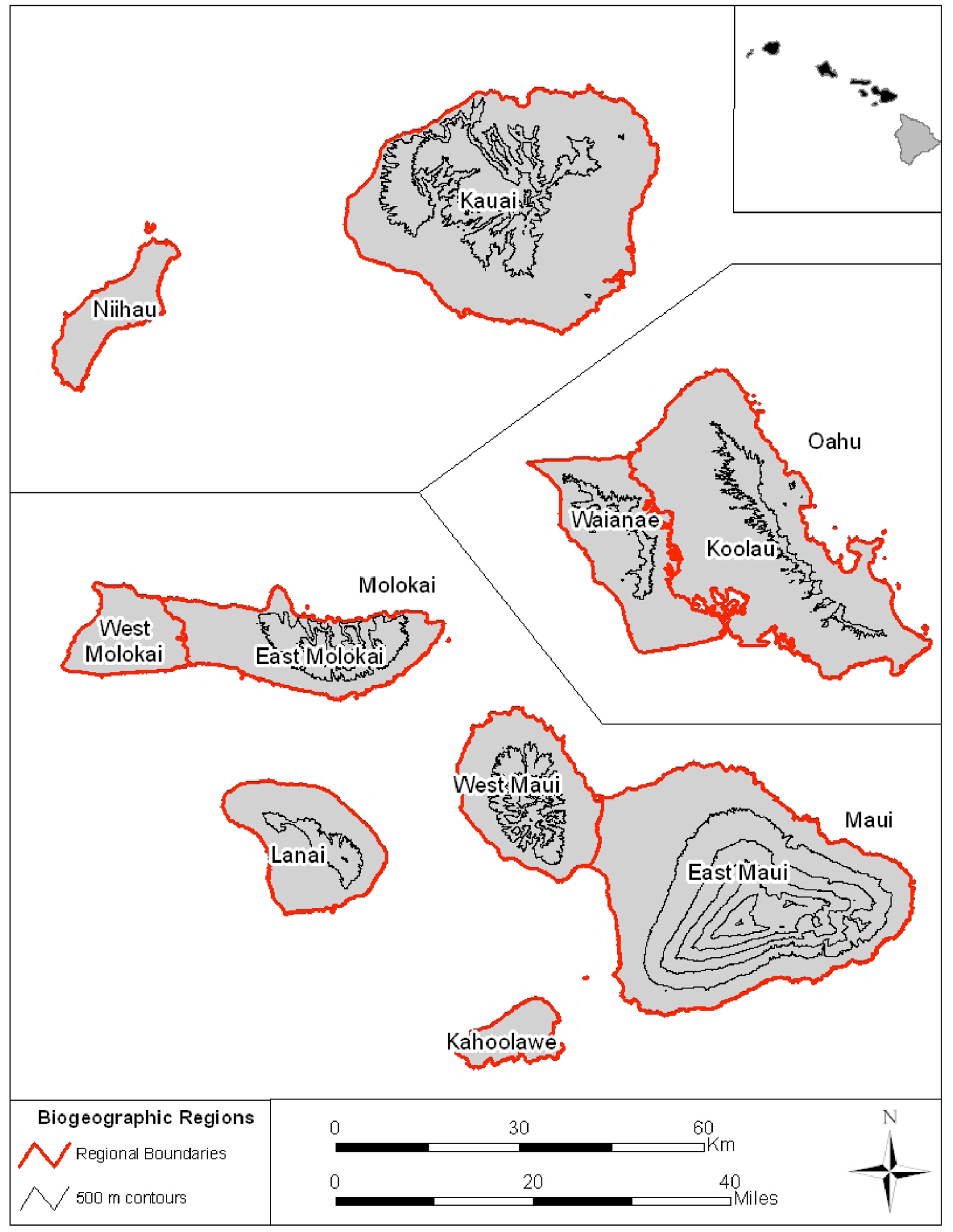

Figure 7. Biogeographic regions on Ni'ihau, Kaua‘i, O’ahu, Moloka‘i, Lāna‘i, Maui, and Kaho'olawe. 


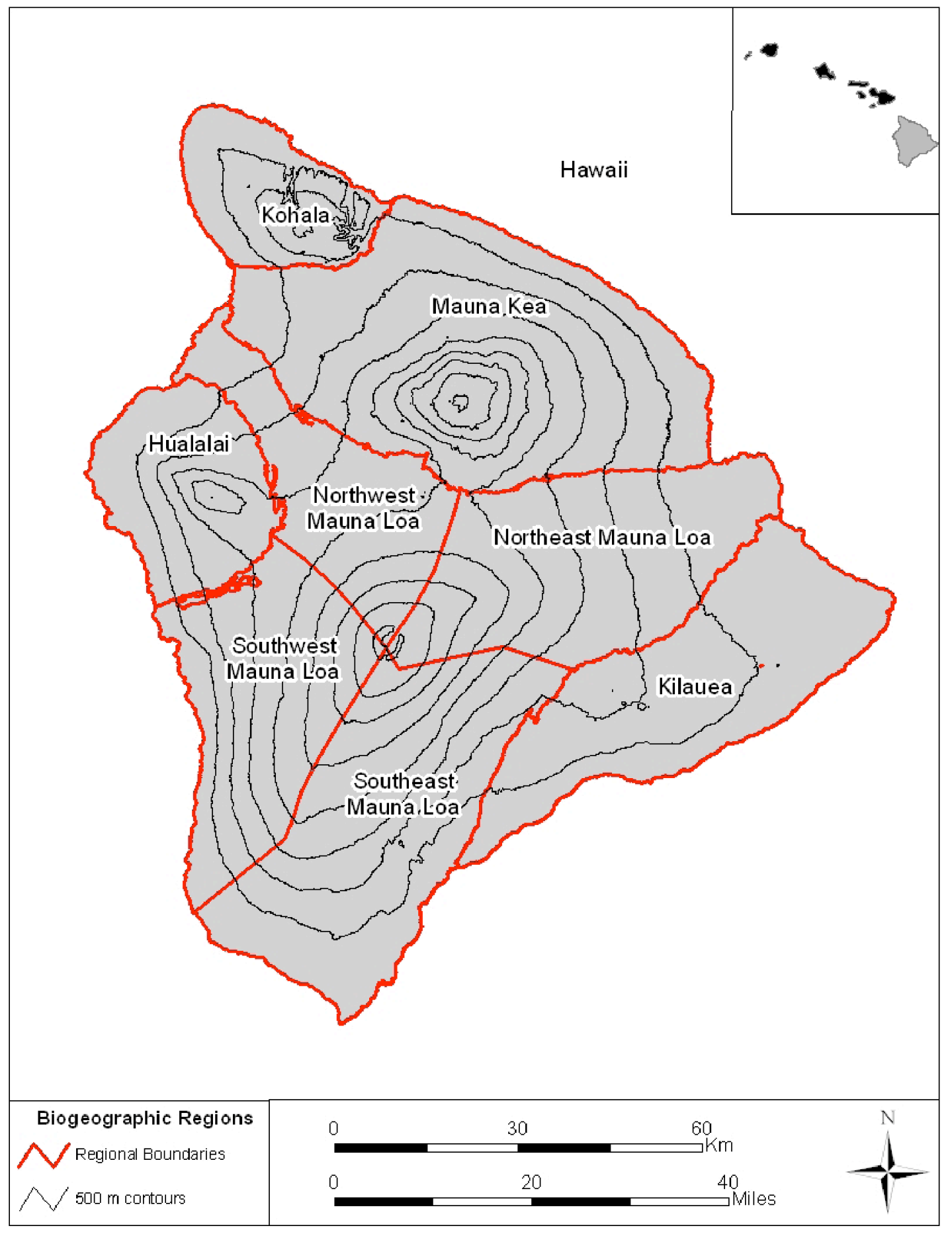

Figure 8. Biogeographic regions on island of Hawai'i. 
generated from a composite geology coverage for the island of Hawai'i (Wolfe and Morris, 1996), as well as from a statewide DEM (USGS open-source data) and a land-parcel-boundary coverage (State of Hawai'i Office of Planning, 2006).

\section{Human Impact}

Many habitats in the Hawaiian Islands have been severely altered by human activity. Areas that have been converted for urban use or intensive agriculture are likely inimical to the vast majority of native species. In addition to these areas, many ecosystems in the Hawaiian Islands are now dominated by nonnative species (Cuddihy and Stone, 1990; Gagné and Cuddihy, 1990), which probably also contribute to the limiting of many native species. On the other hand, certain native species, even some rare and endangered species, may persist in habitats that are dominated by nonnative species. A map by Gon and others (1998) categorized areas as being generally either native or nonnative dominated.

To more precisely identify areas where native species may presently be found, a map was generated that considers the following three categories of habitat quality: High, areas dominated by native vegetation; Medium, areas dominated by nonnative vegetation; and Low, highly modified landscapes. The primary source for mapping these three categories is the HIGAP land-cover classification (Gon, 2006). The High category includes all HIGAP land-cover classes that are considered to be either native dominated or mixed native and nonnative in order to represent those areas that have substantial native-species composition. The Medium category includes areas that are dominated by nonnative species but are not otherwise intensively developed. This incorporates all nonnativedominated HIGAP land-cover classes. The Low category includes all land-cover classes pertaining to urban land, other developed lands, and active cropland. In addition, many areas of former or fallow cropland were mapped as grassland or alien forest in the HIGAP land-cover map. These are best included in the Low category because they include areas where all native vegetation was removed at one time. These areas are different from other nonnative-dominated areas where native species may be more likely to have persisted.

A GIS layer of the agricultural land-use map developed by the State of Hawai' $i$ Department of Agriculture (1980) was generated into a 30-m grid, and then all cells identified as cropland and other intensive agricultural uses were reclassified into the Low-habitat-quality category. In addition, areas classified as "Very Sparse Vegetation to Unvegetated" in the HIGAP land-cover map cannot be directly attributed to a given habitat quality because they may represent native pioneer vegetation on lava or barren sites within a nonnative-dominated area. Therefore, the average habitat-quality value was assigned to each unvegetated cell for all cells within a $3 \mathrm{~km}$ radius. Owing to limitations in the accuracy of the HIGAP land-cover map, the resulting map is still somewhat general but otherwise represents a good approximation of habitat quality (figs. 9, 10).

To test whether or not native species tend to be found in areas considered as native dominated on the three-level habitat-quality map, a set of point locations that show where rare native plant species are known to be found were used. The data, which were compiled by the U.S. Fish and Wildlife Service, consist of 5,575 locations and represent over 600 species. Points that had the highest precision were selected, and those where the location was overly general (for example, "Ko 'olau Mountains") were excluded. The points were then converted to a grid coverage, and the number of locations associated with each of the three habitat-quality categories was determined. High-habitat-quality areas make up only 46 percent of all land area but include 75 percent of the rare-native-plant-species locations. In addition, Medium-habitat-quality areas make up 41 percent of all land area but include just 23 percent of the rare-native-plant-species locations, whereas Low-habitat-quality areas make up 13 percent of all land area but include less than 2 percent of the rare-native-plant-species locations. In fact, nearly all of the rare-native-plant-species locations associated with Low habitat quality represented Abutilon menziesii, a peculiar endangered species that persists in former sugar cane fields. The habitat-quality designations, 


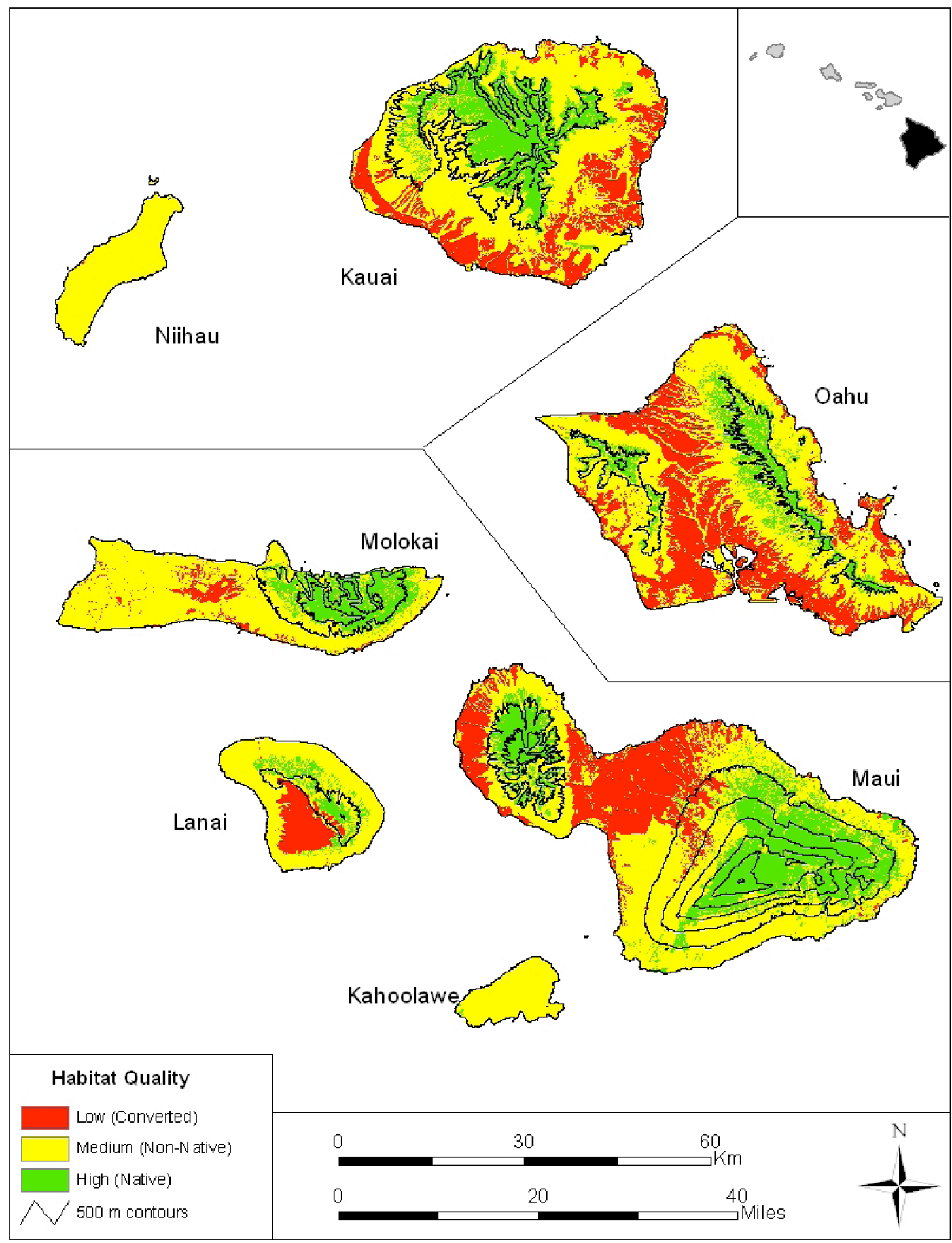

Figure 9. Habitat-quality regions on Ni'ihau, Kaua‘i, O‘ahu, Moloka‘i, Lāna'i, Maui and Kaho'olawe. 


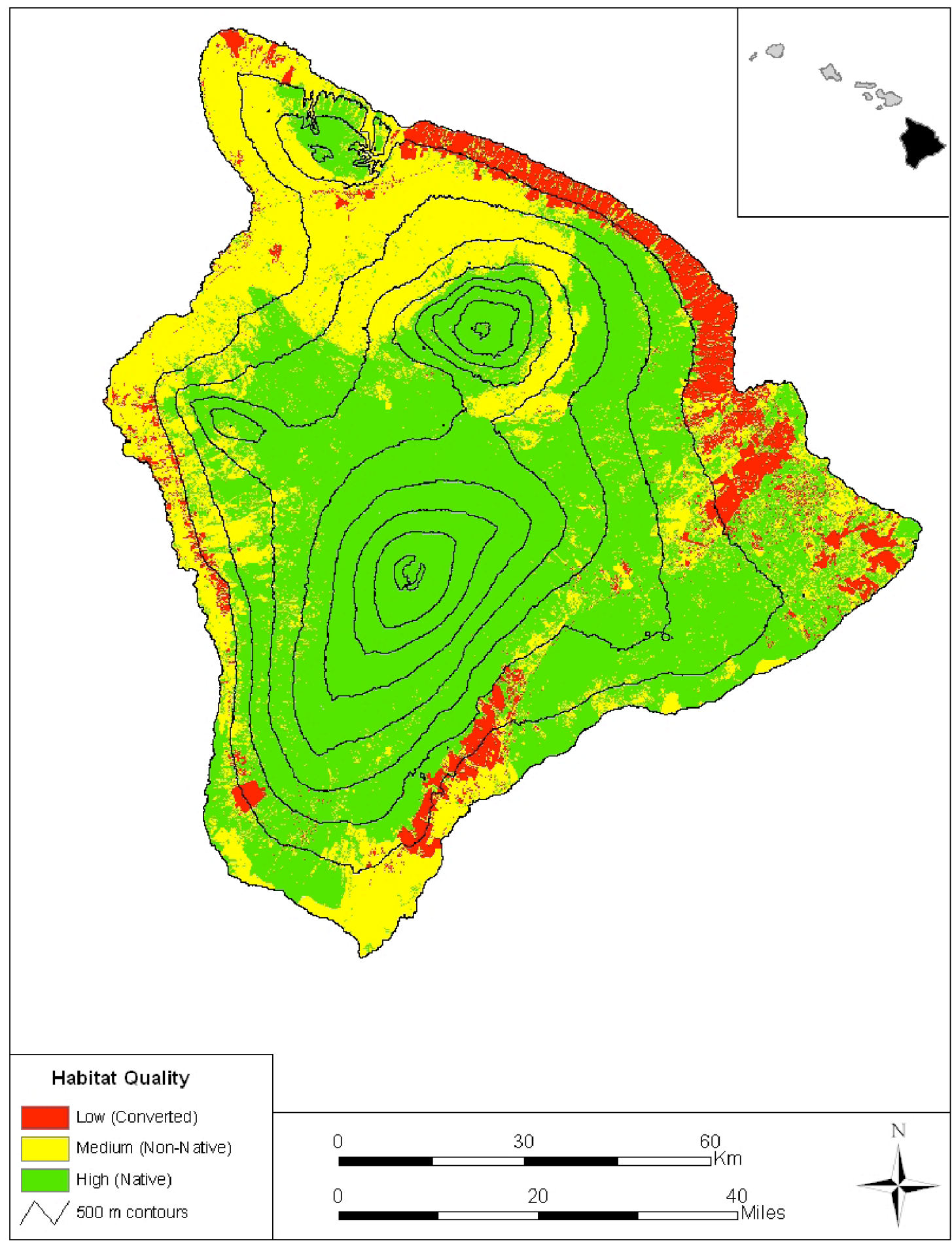

Figure 10. Habitat-quality regions on island of Hawai'i. 
therefore, reflect the tendency of native species to be strongly associated with High habitat quality, nominally associated with Medium habitat quality, and minimally associated with Low habitat quality.

\section{Additional Factors Influencing Species Ranges}

Several other influences on species distributions in the Hawaiian Islands deserve mention, although as yet it is not feasible to map them. Different types of topography, including gulches and ridges, as well as various aspects with respect to sun, wind, and moisture, certainly favor some species while restricting others. Unfortunately, although it is feasible to firmly establish a species within a given climate zone, available records often do not consistently contain detailed site information from which a trend might be discerned. And although collecting such data for a few species may be possible, this would likely prove extremely difficult for the entire vascular flora. In addition, presently available DEMs, although they may depict large-scale variations in topography, may not include small-scale topographic features. For example, many species either prefer, or are now restricted to, very steep slopes and cliff faces; such habitats may be present in fairly small pit craters or cracks that are unlikely to be represented at the presently available resolution of DEMs. Another potential influence that could be mapped is soils. At present only very coarse and outdated soil maps exist; however, the Natural Resources Conservation Service is presently developing a new soils map for the island of Hawai' $i$. Hydrography is another influence that can be very important in determining suitable habitat but is at present difficult to map. Large wetland areas can be mapped, for example, but attributing species only to those areas can potentially omit many smaller wetland areas and streambanks that are far from the larger wetland bodies, and this would lead to an underestimate of the species range. In the future, these potential problem areas might be incorporated into more sophisticated species-distribution models. It may also be feasible to build mathematically complex statistical models that are based on trends from parameters drawn from detailed point data.

\section{Species-Range Mapping}

At present the most effective way to map plant-species ranges in the Hawaiian Islands is by demarcating a general bioclimatic envelope within biogeographic regions in which a species is known to have been found. To do this, this study builds upon a database of native Hawaiian plant species that includes data on the distribution of species by geographic region, major habitat type, and elevation range (Price, 2004). These data come from published sources, herbarium specimens, unpublished reports and field notes, and targeted field work. The database has been expanded in several ways to accommodate a comprehensive species-range mapping program. First, the database now includes data for Hawaiian Pteridophytes that are based largely on the recently published flora by Palmer (2002) and also on specimens from the Bishop Museum. It has also been modified to explicitly document species in the climate zones developed here. Where possible, voucher specimens from specific locations (1) document the presence of a species in each applicable climate zone on the zonal map, (2) establish whether it is found on young lava substrates, as defined here, and (3) documents its elevation limits. The full database, derived from that used by Price (2004), contains these data for all native species and also includes referenced sources for each data cell.

To generate a map of the estimated range of a given species, the database is used to generate a script in Arc Macro Language (AML) that can then be read by a Grid Module of ArcInfo (Environmental Systems Research Institute, 2005). This method was favored because a single AML script can run a batch process to generate estimated range maps for many species and also because problems can be intercepted and amended easily. All layers are converted to a 30-m grid of values. First, using layers for climate zones, biogeographic regions, and young lava substrates, as well as a DEM for elevation range, the AML script selects out those areas that have values appropriate to that species. This 
represents the estimated natural range of the species prior to human modification of habitat. In some cases, a species has been recorded in one biogeographic region on a given island but not in another. The species range can also be calculated for where it might have been present in regions in which it has not been recorded. To examine the status of habitat quality within the estimated natural range of a given species, the range can be parsed into areas corresponding to Low, Medium, and High habitat quality. Thus, a given species range can be considered in several different ways on a particular island on which it is known.

To demonstrate how different ways of viewing a range might be practically applied to different species, we selected four species to use as case studies, including two widespread species (Sadleria cyatheoides and Erythrina sandwicensis) and two rare species (Cyanea tritomatha and Chamaesyce kuwaleana). Sample data matrices show presence in biogeographic regions (table 4) and habitat parameters (table 5) for the four case-study species. Sample range maps for these case studies, along with a description of important patterns, are given in figures 11 through 16. Maps for all species modeled can be downloaded using the table in the appendix to this report.

\section{Applications of Estimated-Range Maps}

The estimated-range maps generated using the methods described here can be applied to both natural history questions and conservation management. They can be used either individually for single species applications or collectively for questions pertaining to species assemblages. The following are several proposed applications, several of which are presently being developed.

\section{Facilitating Field Surveys}

Field biologists often require tools to focus search efforts on species likely to be in a given area. Using species-range parameters and associated GIS maps, it is feasible to produce a list of species potentially within a given area. Many members of a given genus often are present on an island but exist in different geographic regions or different habitats. Field biologists can thus employ the tools developed here to help identify species in their survey area. In other cases, surveys for rare species can be guided by focusing on those areas where a species is most likely to occur. For example, in the case study for Cyanea tritomatha (fig. 16), areas of High habitat quality within the estimated range could be targeted to search for the species.

\section{Restoration Efforts}

Large areas in the Hawaiian Islands are now dominated by nonnative species (figs. 9, 10). Even in areas dominated by native species, significant disturbance from nonnative plants and animals (Cuddihy and Stone, 1990) means that many species are likely to have been extirpated from areas in which they formerly were found. At many sites in the state, rare plants have been outplanted in areas where they formerly grew in order to expand wild populations: for example, the silversword (Argyroxiphium sandwicense) on Mauna Kea (Walker and Powell, 1999) and several rare dry-forest species at Ka'ūpūlehu Preserve on Hawai'i (Cabin and others, 2002). In other cases, sites where a given rare species formerly were found are now highly degraded or may be on lands not presently designated for conservation management. In such cases, outplanting may occur at sites designated for conservation and presumed to constitute appropriate habitat. The method employed here presents a reasonable estimate of suitable habitat for each given species, although other site characteristics such as substrate or soil type, degree of canopy closure, and associated species must also be taken into consideration. For example, the case study of Chamaesyce kuwaleana (fig. 15) suggests that, despite severe alteration of its habitat, suitable restoration sites may be available within its estimated natural range. Producing a list of all species appropriate for a given area will facilitate diverse, community-level ecological restoration. 
Table 4. Biogeographic regions for case-study species.

[For each species, "X" indicates that record exists for that species from given biogeographic region]

\begin{tabular}{|c|c|c|c|c|c|c|c|c|c|c|c|c|c|c|c|c|c|c|}
\hline Species & 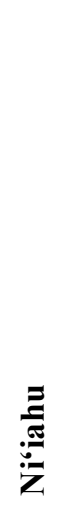 & 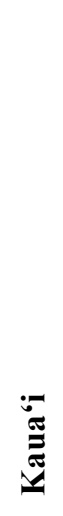 & 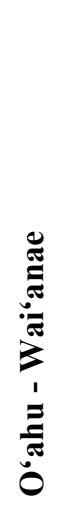 & 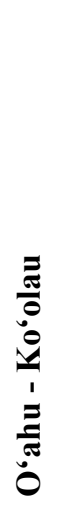 & 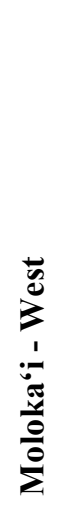 & 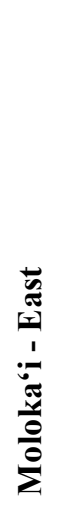 & & 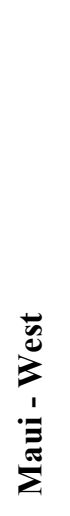 & 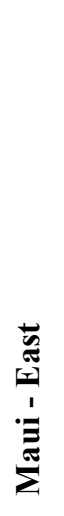 & 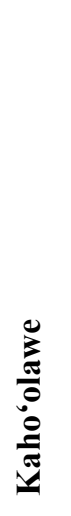 & 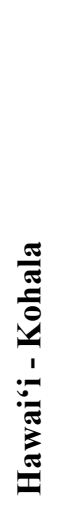 & 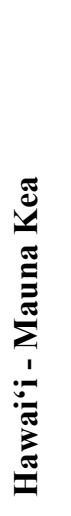 & 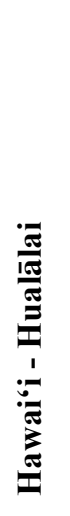 & 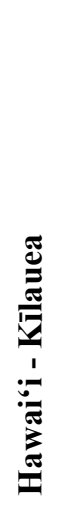 & 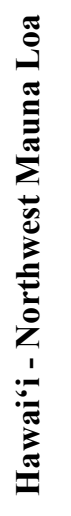 & 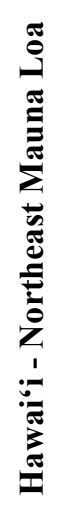 & 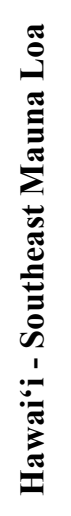 & 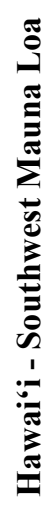 \\
\hline Sadleria cyatheoides & & $\mathrm{X}$ & $\mathrm{X}$ & $\mathrm{X}$ & & $\mathrm{X}$ & $\mathrm{X}$ & $\mathrm{X}$ & $\mathrm{X}$ & & $\mathrm{X}$ & $\mathrm{X}$ & $\mathrm{X}$ & $\mathrm{X}$ & $\mathrm{X}$ & $\mathrm{X}$ & $\mathrm{X}$ & $X$ \\
\hline Erythrina sandwicensis & $\mathrm{X}$ & $\mathrm{X}$ & $\mathrm{X}$ & $\mathrm{X}$ & $\mathrm{X}$ & $\mathrm{X}$ & $\mathrm{X}$ & $\mathrm{X}$ & $\mathrm{X}$ & $\mathrm{X}$ & $\mathrm{X}$ & $\mathrm{X}$ & $\mathrm{X}$ & $\mathrm{X}$ & $\mathrm{X}$ & $\mathrm{X}$ & $\mathrm{X}$ & $x$ \\
\hline Cyanea tritomatha & & & & & & & & & & & $\mathrm{X}$ & $\mathrm{X}$ & & & & $\mathrm{X}$ & $\mathrm{X}$ & \\
\hline Chamaesyce kuwaleana & & & $\mathrm{X}$ & $\mathrm{X}$ & & & & & & & & & & & & & & \\
\hline
\end{tabular}

Table 5. Habitat parameters for case-study species.

[For each species, "X" indicates that a record exists for that species from given biogeographic region]

\begin{tabular}{|c|c|c|c|c|c|c|c|c|}
\hline Species & 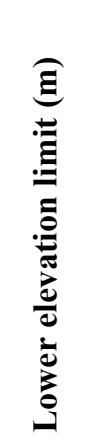 & 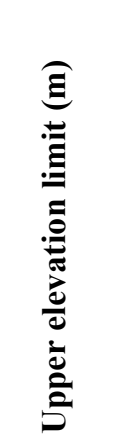 & 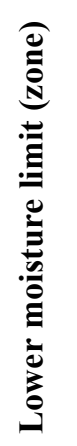 & 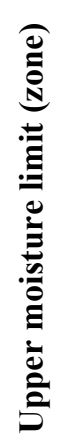 & 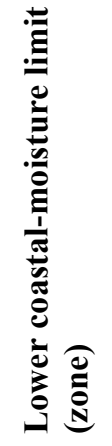 & 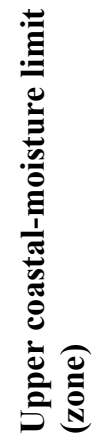 & 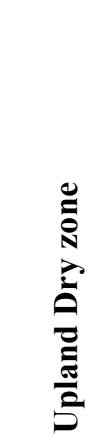 & 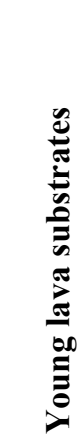 \\
\hline Sadleria cyatheoides & 5 & 2,348 & 4 & 7 & 4 & 7 & $\mathrm{X}$ & \\
\hline Erythrina sandwicensis & 0 & 854 & 1 & 4 & 1 & 5 & & $\mathrm{X}$ \\
\hline Cyanea tritomatha & 350 & 1,524 & 6 & 7 & 0 & 0 & & \\
\hline Chamaesyce kuwaleana & 10 & 500 & 2 & 3 & 2 & 3 & & \\
\hline
\end{tabular}




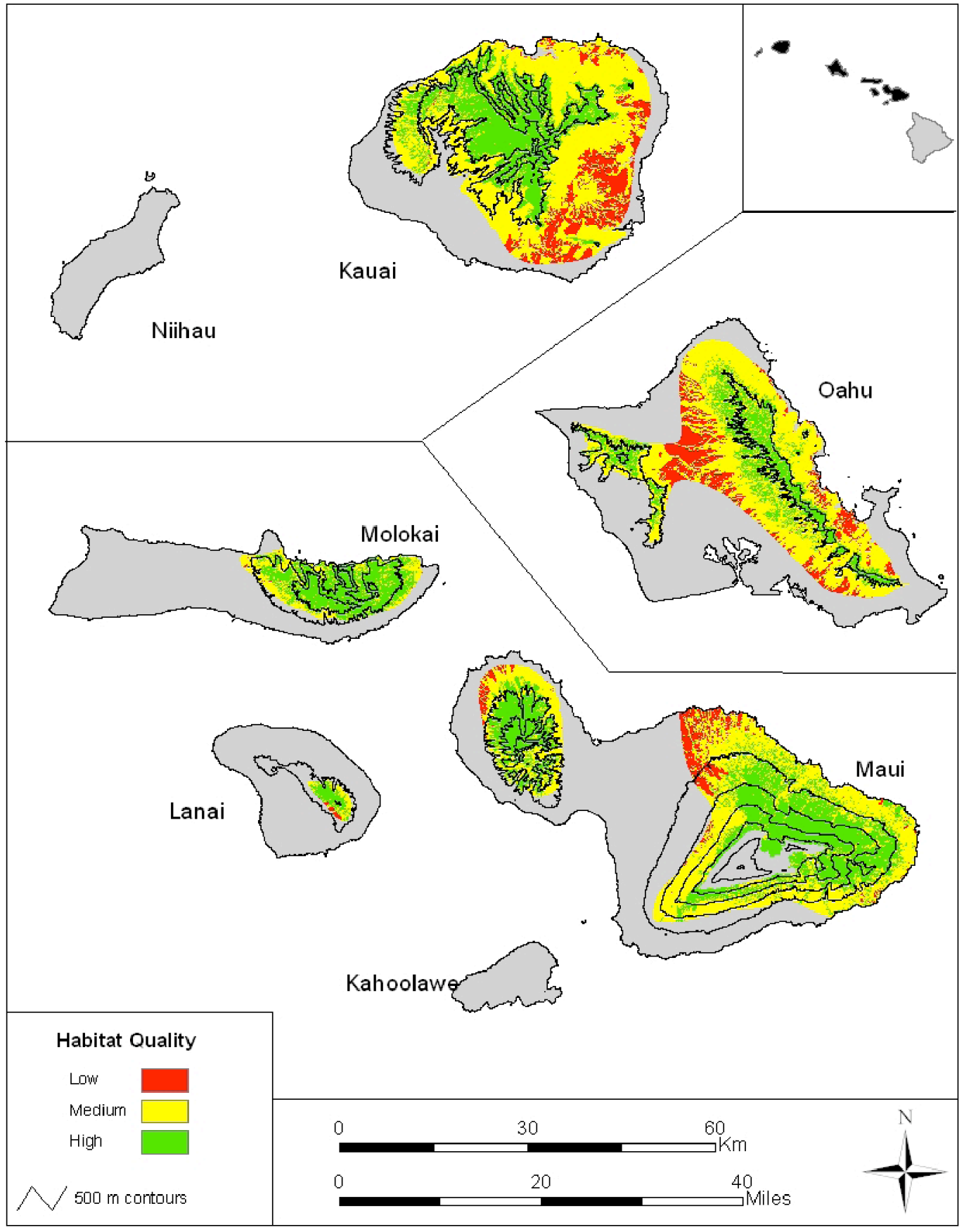

Figure 11. Habitat quality across modeled range of Sadleria cyatheoides on Ni'ihau, Kaua'i, O'ahu, Moloka'i, Lāna'i, Maui, and Kaho'olawe. This species is known from Mesic and Wet habitats (moisture zones 4 through 7) across wide elevational range on many islands; it also extends into dryer areas in upper elevations on Maui and Hawai'i (Upland Dry Zone) but does not extend into drier habitats at lower elevations. Status of habitat for this species reflects commonly seen pattern for upland Wet/Mesic species in which much of estimated natural range remains in High- or Medium-quality habitat. 


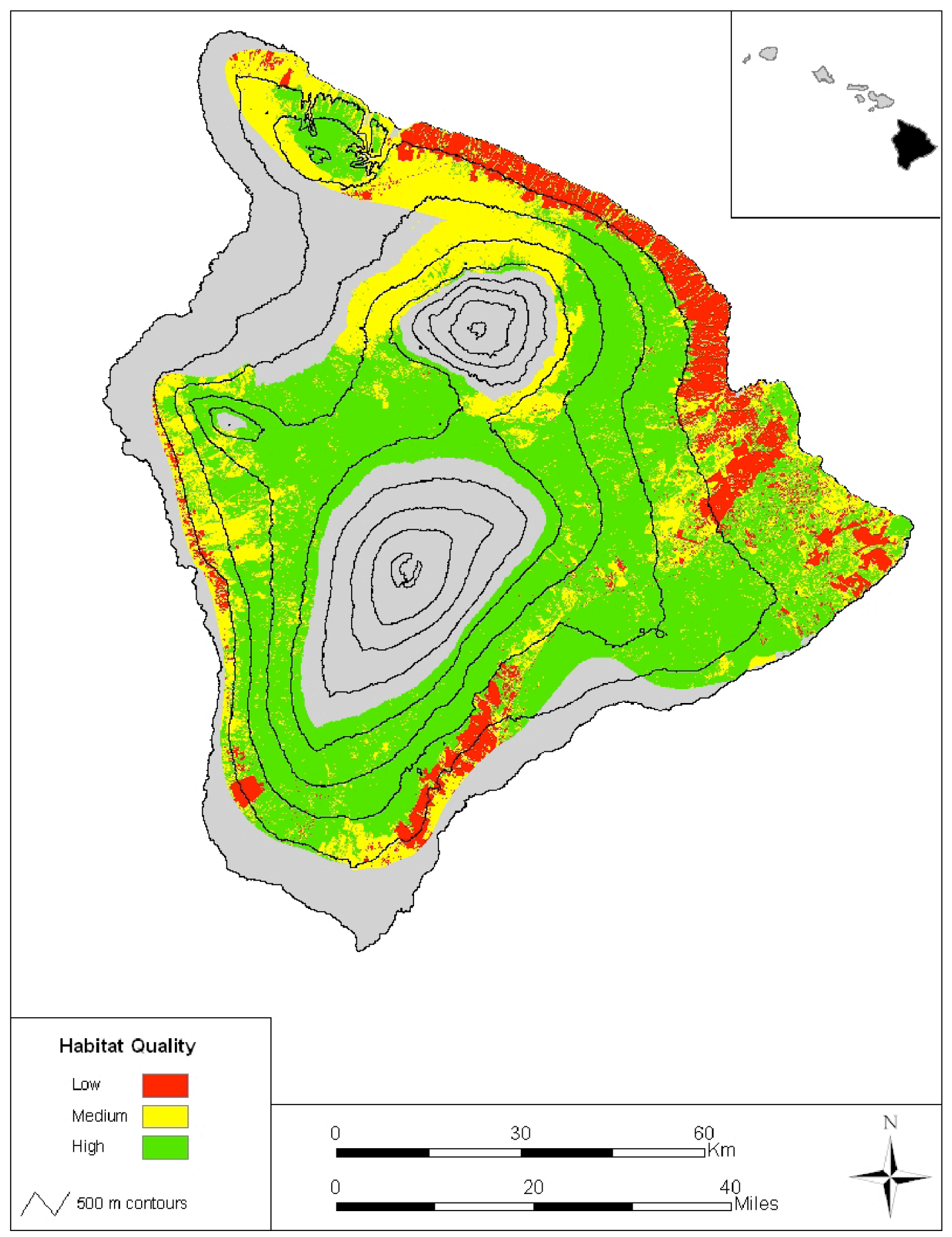

Figure 12. Habitat quality across modeled range of Sadleria cyatheoides on island of Hawai i. 


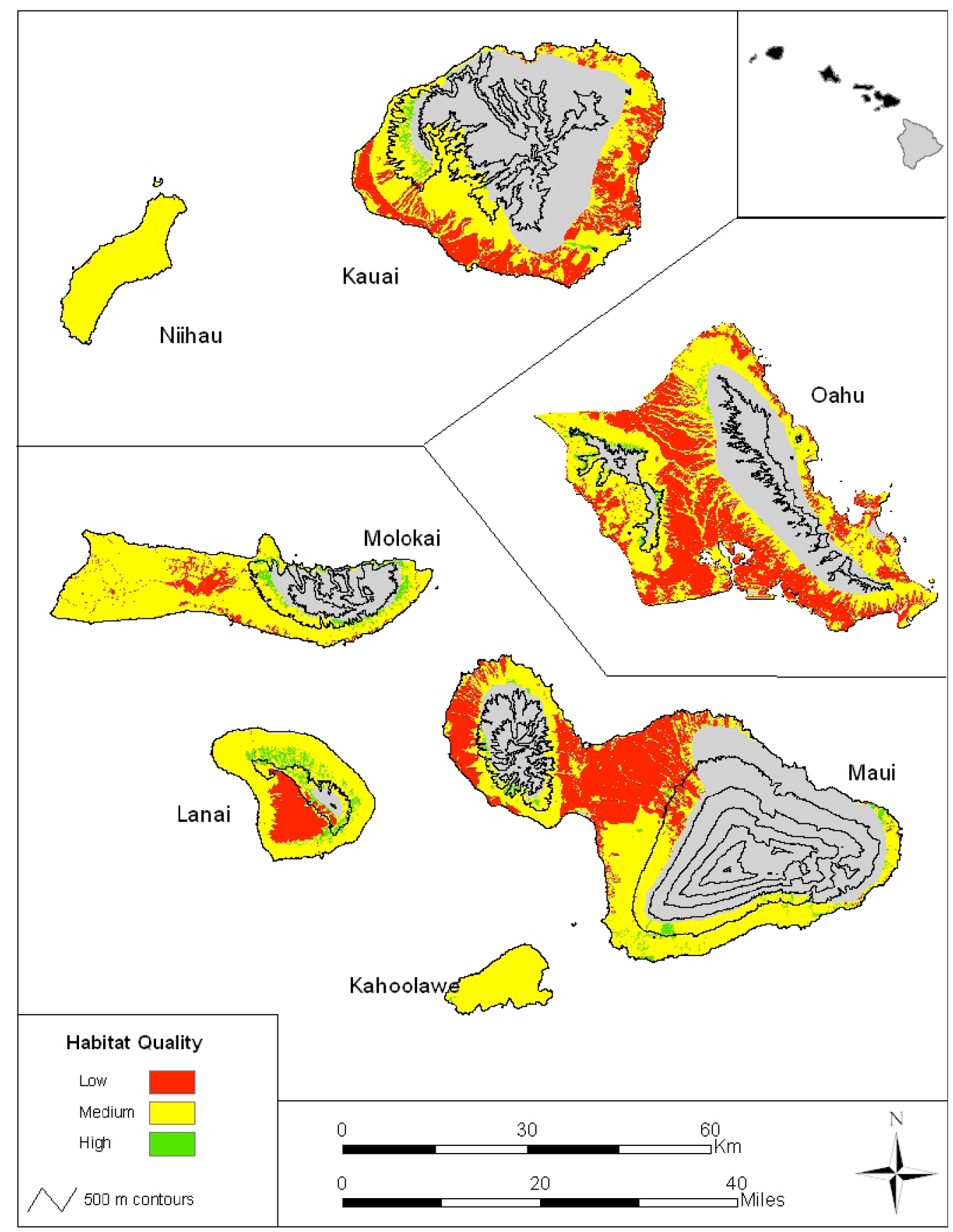

Figure 13. Habitat quality across modeled range of Erythrina sandwicensis on Ni'ihau, Kaua'i, O'ahu, Moloka'i, Lāna'i, Maui, and Kaho'olawe. This species is known from Arid to Seasonal Mesic habitats (moisture zones 1 through 4) at low elevations on many islands; it also extends into Moist Mesic areas (Zone 5) along coast but not inland. Status of habitat for this species is typical for species restricted to drier lowland areas where much of estimated natural range is Medium- or Low-quality habitat. 


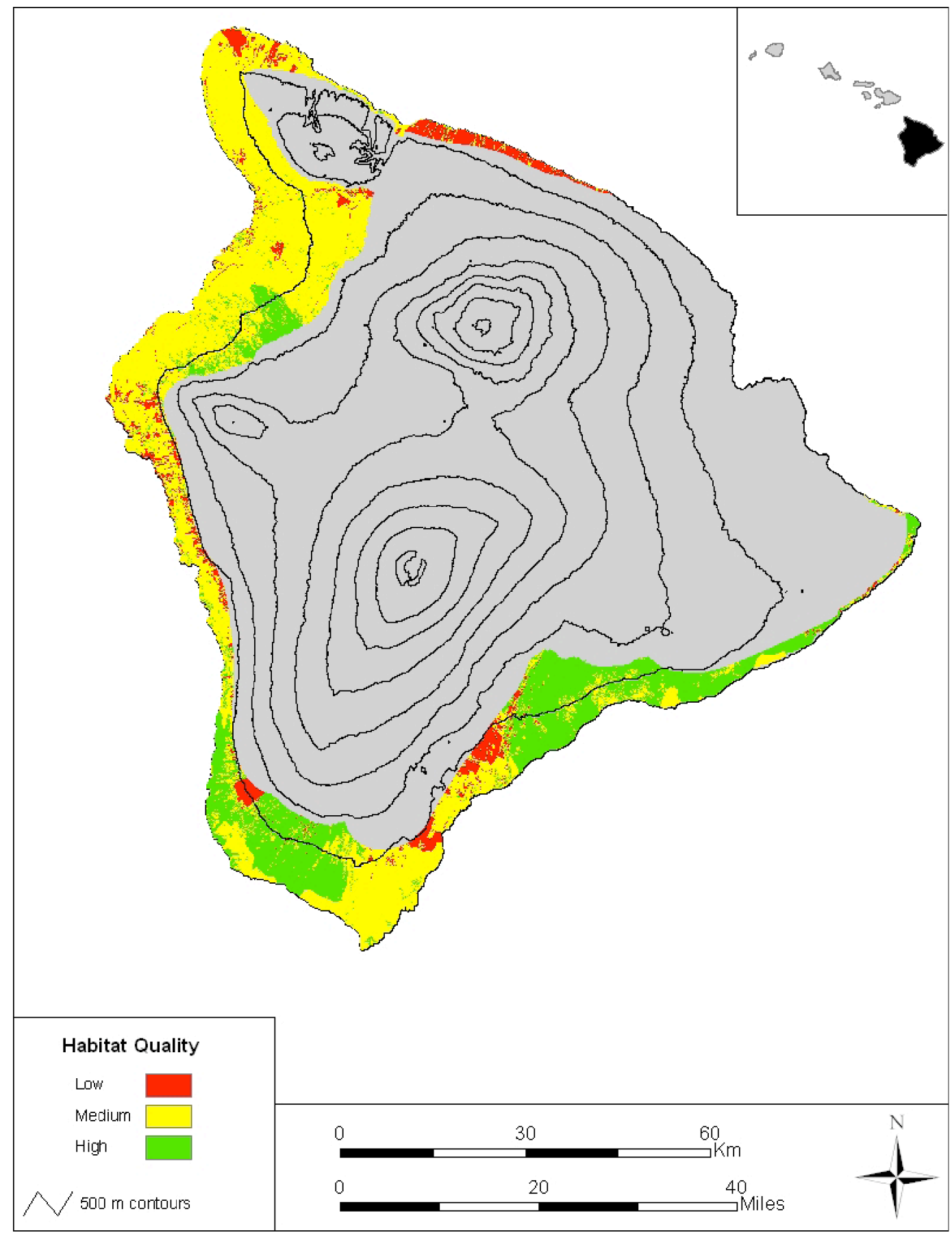

Figure 14. Habitat quality across modeled range of Erythrina sandwicensis on island of Hawai'i. 


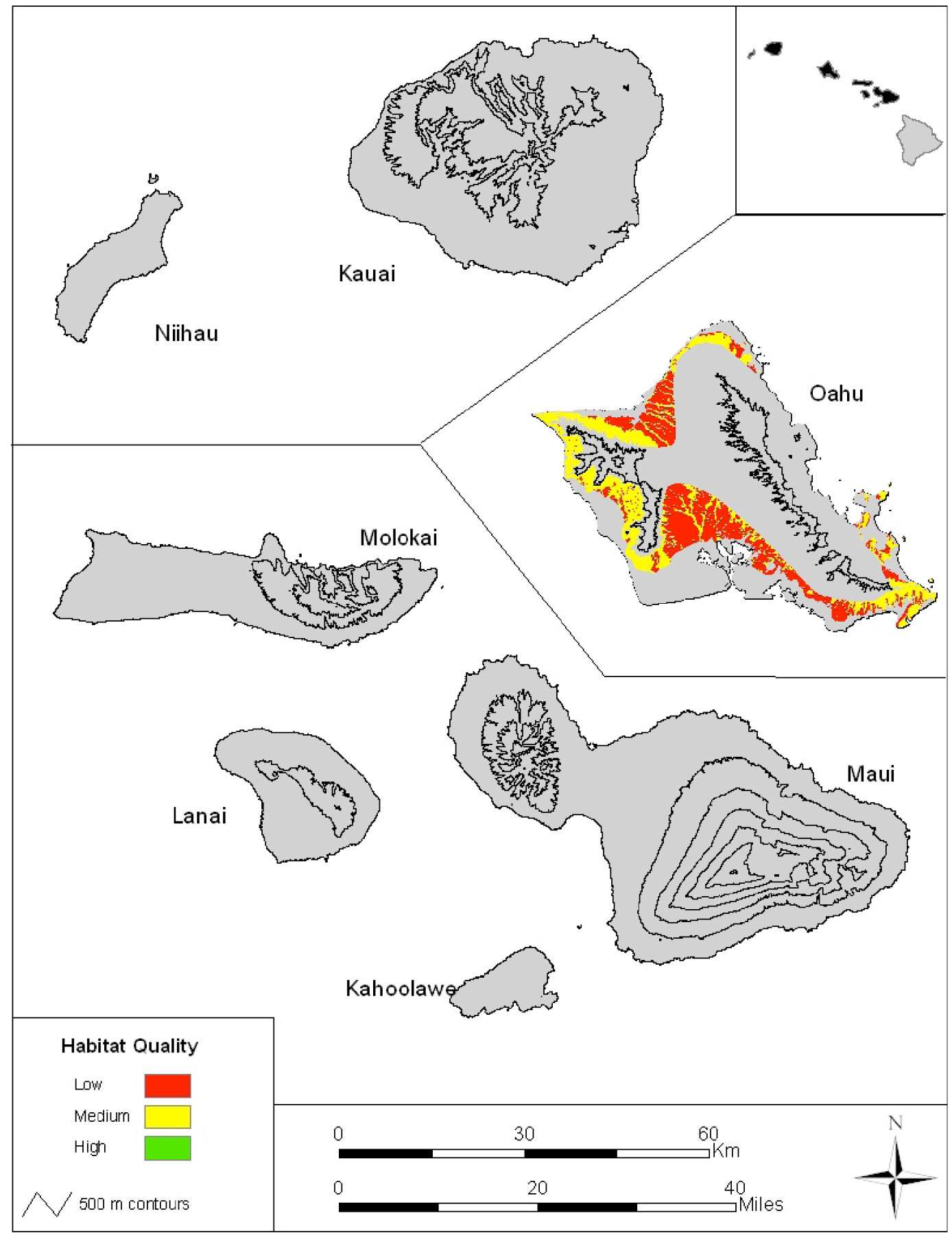

Figure 15. Habitat quality across modeled range of Chamaesyce kuwaleana, restricted to O'ahu. 


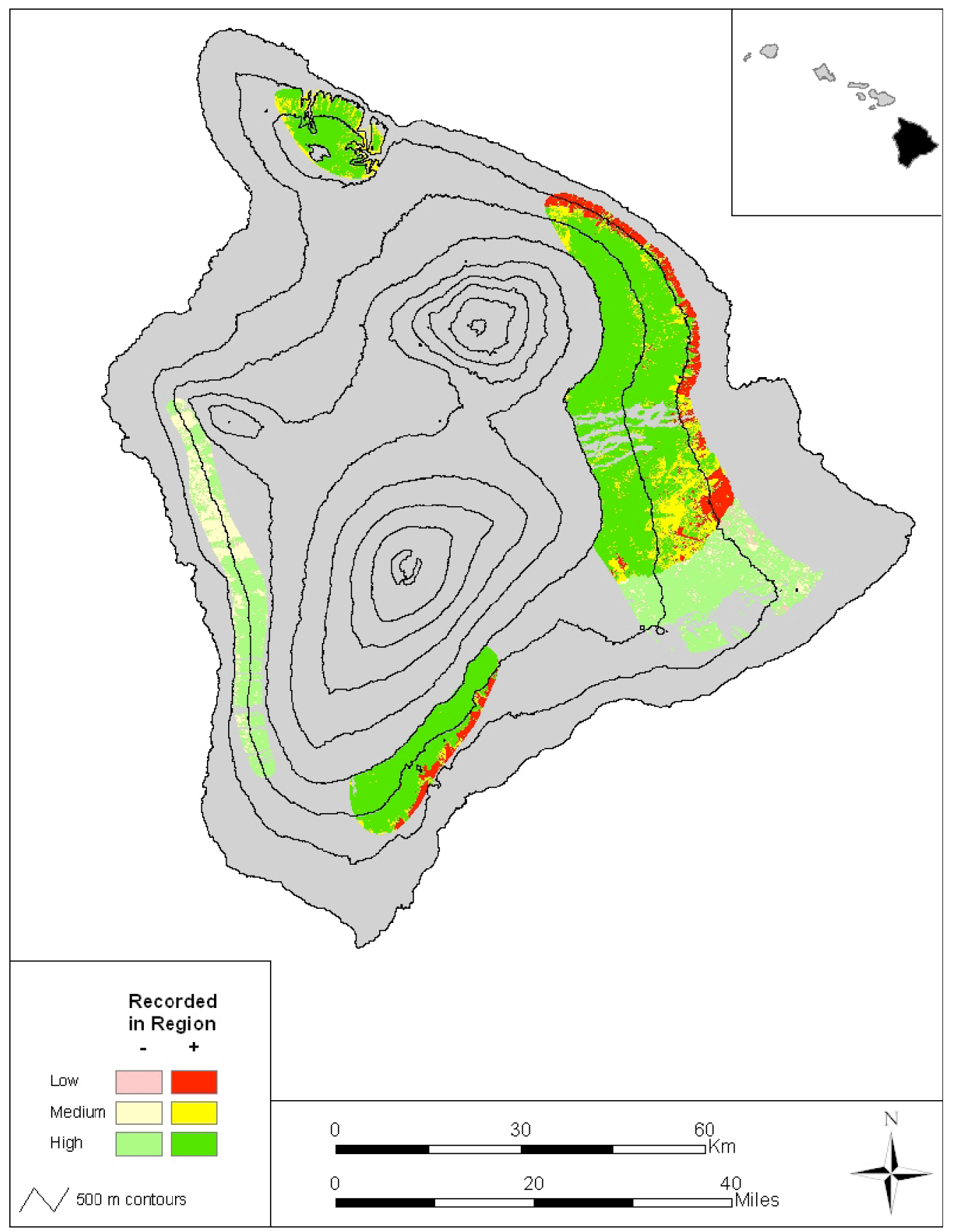

Figure 16. Habitat quality across modeled range of Cyanea tritomantha, restricted to island of Hawai' $i$. This species is known from only a few biogeographic regions on one island, Hawai'i. Darker colors (+) show areas where Cyanea tritomantha has been recorded; lighter colors (-) depict areas where it has not been recorded. Many species exhibit this pattern in which part of island may have appropriate habitat for a species, but that species has never been recorded there. In some cases, a species is naturally restricted; in other cases, there has been insufficient sampling in its potential habitat. 


\section{Studies of Range Size and Rarity}

A growing body of work seeks to understand the causes of variation in the size of species' geographic ranges in the Hawaiian Islands. Many geographically restricted species are threatened with extinction, and, therefore, information about the nature of their rarity may be useful to their conservation (Gaston, 2002). Nearly half of Hawaiian plant species are naturally restricted to a single island (Price, 2004), and this rarity is correlated with restriction to few habitats and a narrow elevation range (Price and Wagner, 2004). The method presented here produces comparatively precise estimates of both the natural range size and the probable actual present-day range size (by taking into account human-induced range reduction). These two estimates vary independently among species, and, therefore, a species that is presently rare may have been quite common in the past. For example, in the case study for Eythrina sandwicensis (figs. 13, 14), which is a species that was probably extremely widespread prior to human landscape modification, has undergone range reduction so that it is now somewhat rare. By comparison, the case study for Cyanea tritomantha (fig. 16) suggests that this species was already somewhat rare prior to human landscape modification. This distinction between human-induced rarity and natural rarity may have important management implications, as naturally rare species may be better adapted to maintaining small populations than species that have lost much of their original population structure (Gaston, 1994).

\section{Studies of Biodiversity}

Examinations of patterns in biodiversity frequently use species-richness maps produced by overlaying the ranges of all species of interest within a region (Flather and others, 1997; Hortal and others, 2001; Lennon and others, 2004). Using the methodology presented here, species-range estimates and derivative species-richness maps are much more highly resolved locally, when compared to other country- or continent-scale maps used in most studies. Using high-resolution species-richness maps, more detailed analyses of the factors contributing to biodiversity are feasible. Although factors such as habitat, elevation, and island age have been examined in the Hawaiian Islands (Price, 2004), more spatially explicit analyses may elucidate complex interactions among factors not apparent through other analyses.

\section{Conservation Planning}

Species range maps may be employed in a Gap Analysis Program (GAP), in which they are compared to the spatial placement of conservation areas in order to identify gaps in conservation efforts (Scott and others, 1993). The national GAP seeks to incorporate this type of analysis for all U.S. states to produce a comprehensive evaluation of biodiversity conservation (Scott and Csuti, 1992). The Hawai' $i$ GAP is unique among these in incorporating endangered plant-species ranges, rather than vertebrates only as in other state GAPs (Gon, 2006). Nonetheless, debate continues as to whether GAP appropriately incorporates critical aspects of species conservation (Burley, 1988; Flather and others, 1997). Although the GAP for the Hawaiian Islands considered federally endangered plant species only, examination of all plant species may produce different results. Moreover, alternative measures of conservation value, independent of federal listing or total richness, may be feasible. Potential measures include richness of species that show natural geographical rarity or richness of species that show humaninduced rarity (that is, having small range size after human impact). The comprehensive nature of these measures of conservation value, coupled with their comparative detail, may promote landscape-scale tools for conservation planning not possible in other regions. 


\section{Invasive Species Management}

Invasive plant species pose a serious threat to Hawaiian ecosystems by displacing and competing with native plant species and disrupting key ecological processes (Cuddihy and Stone, 1990).

Conservation agencies and organizations expend considerable resources to control highly invasive plant species such as Miconia calvescens. New invasive threats appear each year as incipient populations expand. By using known or projected environmental parameters, the potential range of a given invasive species can be estimated. Using such an estimated range can help assess the degree of threat posed by a given invasive species and may inform management efforts to strategically search for and control incipient populations before the species becomes a widespread problem. For example, a study of several nonnative species on Maui by Price and Jacobi (2006) used similar methodology to assess the potential for range expansion relative to presently known distributions. The resulting analysis may inform strategic plans for control of species that are considered most likely to expand their ranges and, thus, negatively impact native ecosystems or rangeland resources.

\section{Summary and Future Modeling Efforts}

The tools and methods presented here provide a simple but comprehensive way to generate maps of the estimated natural ranges and probable present-day ranges of Hawaiian plant species. Nonetheless, these estimates will need to be reassessed or refined periodically. The prospect of new location data that is based on continued fieldwork may result in new parameters that necessitate reassessing the range estimate for a given species. For example, species continue to be discovered on islands or in habitats where they were previously unknown. The development of new GIS layers (including soils, geomorphology, and highly refined canopy cover), coupled with point-quality location data for all known locations of a given plant species, will promote more sophisticated modeling methodologies that are based on probability and include error estimates, capable of being subjected to rigorous model testing. At present, however, the methodology documented here presents a useful first approximation of the ranges of Hawaiian plant species not previously available.

\section{Acknowledgments}

This research was made possible, in part, thanks to support from U.S. Fish and Wildlife Service (Cooperative Agreement FWS IA 1416000687 930) and the U.S. Geological Survey (USGS) Invasive Species Program. We would like to thank Rick Warshauer of the Hawai' $i$ Cooperative Studies Unit and

Linda Pratt of the USGS Pacific Island Ecosystems Research Center for offering much of their extensive knowledge of Hawaiian ecosystems. Tom Giambelluca of the University of Hawai ' $i$ at Mānoa provided important insights into Hawaiian climate, and Dave Sherrod of the USGS supplied digital geological maps. Three anonymous reviewers also provided many useful comments on the manuscript. We would also like to acknowledge support provided by the Pacific Island Ecosystems Research Center through the USGS Invasive Species Program, including federal staff support and administration, as well as for support by personnel hired by the Research Corporation of the University of Hawai ' $i$ and administered through the USGS Hawai' $i$ Cooperative Study Unit, University of Hawai'i at Hilo. Additional administrative support and personnel were provided as part of a cooperative project with the University of Hawai 'i at Mānoa, through the Pacific Cooperative Studies Unit. 


\section{References Cited}

Aplet, G.H., and Vitousek, P.M., 1994, An age-altitude matrix analysis of Hawaiian rain-forest succession: Journal of Ecology, v. 82, p. 137-147.

Austin, A.T., 2002, Differential effects of precipitation on production and decomposition along a rainfall gradient in Hawai'i: Ecology, v. 83, p. 328-338.

Balakrishnan, N., and Mueller-Dombois, D., 1983, Nutrient studies in relation to habitat type and canopy dieback in the montane rain forest ecosystem, Island of Hawai 'i: Pacific Science, v. 37, p. 339-359.

Bean, C., Juvik, J.O., and Nullett, D., 1994, Mountain evaporation profiles on the island of Hawai' $i$ : Journal of Hydrology, v. 156, p. 181-192.

Burley, F.W., 1988, Monitoring biological diversity for setting priorities in conservation, in Wilson, E.O., ed., Biodiversity: Washington, D.C., National Academy Press, p. 227-230.

Cabin, R.J., Weller, S.G., Lorence, D.H., Cordell, S., Hadway, L.J., Montgomery, R., Goo, D., and Urukami, A., 2002, Effects of light, alien grass, and native species additions on Hawaiian dry forest restoration: Ecological Applications, v. 12, p. 1,595-1,610.

Carlquist, S., 1980., Hawai ‘i-A natural history (2d ed.): Lāwa'i, Kaua'i, Hawai ‘i, Pacific Tropical Botanical Garden, 468 p.

Crews, T.E., Kitayama, K., Fownes, J.H., Riley, R.H., Herbert, D.A., Mueller-Dombois, D., and Vitousek, P.M., 1995, Changes in soil phosphorus fractions and ecosystem dynamics across a long chronosequence in Hawai'i: Ecology, v. 76, p. 1,407-1,424.

Cuddihy, L., and Stone, C.P., 1990, Alteration of native Hawaiian vegetation-Effects of humans, their activities and introductions: Mānoa, University of Hawai 'i, Cooperative National Park Resources Studies Unit, 138 p.

Environmental Systems Research Institute, 2005, ArcGIS v. 9.1.

Flather, C.H., Wilson, K.R., Dean, D.J., and McComb, W.C., 1997, Identifying gaps in conservation networks of indicators and uncertainty in geographic-based methods: Ecological Applications, v. 7, p. $531-542$.

Gagné, W.C., and Cuddihy, L.W., 1990, Vegetation, in Wagner, W.L., Herbst, D.R., and Sohmer, S.H., eds., Manual of flowering plants of Hawai' $i$ : Honolulu, University of Hawai 'i and Bishop Museum Press, p. 45-114.

Gaston, K.J., 1994, Rarity: London, Chapman and Hall, 207 p.

Gaston, K.J., 2002, The structure and dynamics of geographic ranges: New York, Oxford University Press, $266 \mathrm{p}$.

Giambelluca, T., and Schroeder, T.A., 1998, Climate, in Juvik, J.O., Juvik, S.P., and Paradise, T.R., eds., Atlas of Hawai'i: Honolulu, University of Hawai'i Press, p. 49-59.

Giambelluca, T.W., Nullett, M.A., and Schroeder, T.A., 1986, Rainfall atlas of Hawai'i: Hawai'i Department of Land and Natural Resources, Division of Water and Land Development, Technical Report, 267 p.

Gon, S.M., III, 2006, The Hawai'i Gap Analysis Project final report: Honolulu, University of Hawai 'i, Research Corporation of the University of Hawai' $i, 163$ p.

Gon, S.M., III, Dorfman, D.S., Matsuwaki, D.H., and EcosystemDataGroup, 1998, Ecosystem GIS data-GIS data on CD-ROM: Honolulu, Hawai'i Natural Heritage Program.

Hillebrand, W., 1888, Flora of the Hawaiian Islands (facsimile reprint of original edition): New York, Hefner Publishing Co., 673 p.

Holdridge, L.R., 1967, Life zone ecology: San Jose, Costa Rica, Tropical Science Center, 206 p. 
Hortal, J., Lobo, J.M., and Martin-Piera, F., 2001, Forecasting insect species richness scores in poorly surveyed territories - The case of Portuguese dung beetles (Col. Scarabidae): Biodiversity and Conservation, v. 10, p. 1,343-1,367.

Jacobi, J.D., 1989, Vegetation maps of the upland plant communities on the islands of Hawai'i, Maui, Moloka'i, and Lāna ‘i: Honolulu, University of Hawai 'i Department of Botany, Cooperative National Park Resources Studies Unit, Technical Report 68, 25 p.

Juvik, J.O., and Ekern, P.C., 1978, A climatology of mountain fog on Mauna Loa, Hawai'i Island: Honolulu, University of Hawai'i Water Resources Research Center, Technical Report 118, 70 p.

Juvik, J.O., and Tango, L.K., 2003, Climate and water resources, Pu'u Wa'awa'a, North Kona: Report prepared for the Department of Land and Natural Resources, Division of Forestry and Wildlife (under contract from U.S. Fish and Wildlife Service), 67 p.

Juvik, J.O., Singleton, D.C., and Clarke, G.G., 1978, Climate and water balance on the island of Hawai 'i, in Miller, J., ed., Mauna Loa Observatory, a 20th anniversary report: U.S. Department of Commerce, National Oceanic and Atmospheric Administration, Environmental Research Laboratories, p. 129-139.

Kitayama, K., Mueller-Dombois, D., and Vitousek, P.M., 1995, Primary succession of Hawaiian montane rain forest on a chronosequence of eight lava flows: Journal of Vegetation Science, v. 6, p. 211-222.

Lennon, J.J., Koleff, P., Greenwood, J.J.D., and Gaston, K.J., 2004, Contribution of rarity and commonness to patterns of species richness: Ecology Letters, v. 7, p. 81-87.

Palmer, D.D., 2002, Hawai 'i’s ferns and fern allies: Honolulu, University of Hawai ‘i Press, 324 p.

Price, J.P., 2004, Floristic biogeography of the Hawaiian Islands-Influences of area, environment and paleogeography: Journal of Biogeography, v. 31, p. 487-500.

Price, J.P., and Jacobi, J.D., 2006, Assessment of invasive plant species distributions on Haleakalā Ranch, East Maui: Report prepared for U.S. Natural Resources Conservation Service and The Nature Conservancy of Hawai' $i, 81 \mathrm{p}$.

Price, J.P., and Wagner, W.L., 2004, Speciation in Hawaiian angiosperm lineages-Cause, consequence, and mode: Evolution, v. 58, p. 2,185-2,200.

Ripperton, J.C., and Hosaka, E.Y., 1942, Vegetation zones of Hawai 'i: Hawai'i Agricultural Experiment Station Bulletin, v. 89, p. 1-60.

Rock, J.R., 1913, The indigenous trees of the Hawaiian Islands: Rutland, Vermont and Tokyo, Japan, Charles E. Tuttle Co., 518 p.

Scott, J.M., and Csuti, B., 1992, Gap analysis-Blueprint for proactive conservation: Focus on Renewable Natural Resources, v. 17, p. 1-2.

Scott, J.M., Davis, F., Csuti, B., Noss, R.F., Butterfield, B., Groves, C., Anderson, H., Caicco, S., D’Erchia, F., Edwards, T.C., Ulliman, Joe, and Wright, G., 1993, Gap analysis - A geographic approach to protection of biological diversity: Wildlife Monographs, v. 123, p. 1-41.

Sherrod, D.R., Hagstrum, J.T., McGeehin, J.P., Champion, D.E., and Trousdell, F.A., 2006, Distribution, ${ }^{14} \mathrm{C}$ chronology, and paleomagnetism of latest Pleistocene and Holocene lava flows at Haleakalā volcano, Island of Maui, Hawai ‘i-A revision of lava-flow hazard zones: Journal of Geophysical Research, v. 111, 24 p.

Staples, G.W., and Cowie, R.H., eds., 2001, Hawai'i's invasive species-A guide to invasive plants and animals in the Hawaiian Islands: Honolulu, Hawai' $i$, Mutual Publishing and Bishop Museum Press, $114 \mathrm{p}$.

State of Hawai 'i Department of Agriculture, 1980, Agricultural land use maps (digitized in Arc/Info v. 6 by Office of State Planning), scale 1: 24,000.

State of Hawai'i Office of Planning, 2006, Tax map key parcel map. 
Stemmermann, L., and Ihsle, T., 1993, Replacement of Metrosideros polymorpha, 'Ōhi ‘a, in Hawaiian Dry Forest succession: Biotropica, v. 25, p. 36-45.

Thornthwaite, C.W., 1948, An approach towards a rational classification of climate: Geographical Review, v. 38, p. 55-94.

U.S. Fish and Wildlife Service, 2012, Species reports—Listings and occurrences for Hawaii: U.S. Fish and Wildlife Service Environmental Conservation Online System, accessed at http://ecos.fws.gov/ tess_public/pub/stateListingAndOccurrenceIndividual.jsp?state $=\mathrm{HI}$.

Vitousek, P.M., van Cleve, K., Balakrishnan, N., and Mueller-Dombois, D., 1983, Soil development and nitrogen turnover in montane rainforest soils on Hawai'i: Biotropica, v. 15, p. 268-274.

Wagner, W.L., and Funk, V.A., 1995, Hawaiian biogeography-Evolution on a hotspot archipelago: Washington, D.C., Smithsonian Institution Press, 467 p.

Wagner, W.L., and Herbst, D.R., 1999, Supplement to the Manual of the Flowering Plants of Hawai 'i, in Wagner, W.L., Herbst, D.R., and Sohmer, S.H., eds., Manual of the Flowering Plants of Hawai'i: Honolulu, University of Hawai'i Press and Bishop Museum Press, p. 1,855-1,918.

Wagner, W.L., Bruegmann, M.M., Herbst, D.M., and Lau, J.Q.C., 1999, Hawaiian vascular plants at risk-1999: Honolulu, Hawaii, Bishop Museum Press, Bishop Museum Occasional Papers, no. 60, 58 p., available at hbs.bishopmuseum.org/pdf/op60.pdf.

Wagner, W.L., Herbst, D.R., and Lorence, D.H., 2005, Flora of the Hawaiian Islands: Smithsonian National Museum of Natural History database, accessed at http://botany.si.edu/ pacificislandbiodiversity/hawaiianflora/index.htm.

Wagner, W.L., Herbst, D.R., and Sohmer, S.H., eds., 1990, Manual of the Flowering Plants of Hawai' $i$ ( $2 \mathrm{~d}$ ed.): Honolulu, University of Hawai 'i Press and Bishop Museum Press, 1,853 p.

Walker, L.R., and Powell, E.A., 1999, Regeneration of the Mauna Kea silversword Argyroxiphium sandwicense (Asteraceae) in Hawai'i: Biological Conservation, v. 89, p. 61-70.

Wolfe, E.W., and Morris, J., 1996, Geologic Map of the Island of Hawai 'i: U.S. Geological Survey Miscellaneous Investigation Series I-2524-A, 18 p., 3 sheets, scale 1:100,000. 


\section{Appendix. Modeled Historic Range Maps for Hawaiian Vascular Plant Species}

This appendix contains maps that show the modeled ranges of 1,158 Hawaiian plant species, including all native Hawaiian vascular plant species that have enough data for modeling their range. For this initial mapping effort, the plants were only mapped at the species level. Species taxonomy follows Wagner and others (1990).

Accompanying the maps is a table entitled "of2012-1192_appendix-table.pdf." Each species contains an entry that includes information on its family name, common name, conservation status, and native status, according to the Smithsonian National Museum of Natural History's Flora of the Hawaiian Islands database (Wagner and others, 2005). In addition, the table lists the type of range map modeled in this study and also includes links to the range maps, which can be downloaded either in JPG format or as GIS shapefiles.

The following is a excerpt from the table, in addition to a list of the table's fields and an explanation of their content.

\begin{tabular}{|c|c|c|c|c|c|c|c|}
\hline Name & Family & $\begin{array}{l}\text { Common } \\
\text { Name }\end{array}$ & $\begin{array}{l}\text { Conservation } \\
\text { Status }\end{array}$ & $\begin{array}{l}\text { Native } \\
\text { Status }\end{array}$ & $\begin{array}{l}\text { Map } \\
\text { Type }\end{array}$ & DOWNLOAD JPG FILES & $\begin{array}{l}\text { DOWNLOAD GIS FILES } \\
\text { (shapefiles, in zip format) }\end{array}$ \\
\hline Abutilon eremitopetalum & Malvaceae & $n / a$ & Endangered & Endemic & Model & $\begin{array}{l}\text { http://pubs.usgs.gov/of/2012/1192/jpgs/ } \\
\text { Abutilon eremitopetalum.jpg }\end{array}$ & $\begin{array}{l}\text { http://pubs.usgs.gov/of/2012/1192/shapefiles/ } \\
\text { abuerem.zip }\end{array}$ \\
\hline Abutilon incanum & Malvaceae & Ma`o & Apparently Secure & Indigenous & Model & $\begin{array}{l}\text { http://pubs.usgs.gov/of/2012/1192/jpgs/ } \\
\text { Abutilon incanum.jpg }\end{array}$ & $\begin{array}{l}\text { http://pubs.usgs.gov/of/2012/1192/shapefiles/ } \\
\text { abuinca.zip }\end{array}$ \\
\hline Abutilon menziesii & Malvaceae & Ko`oloa 'ula & Endangered & Endemic & Model & $\begin{array}{l}\text { http://pubs.usgs.gov/of/2012/1192/jpgs/ } \\
\text { Abutilon menziesii.jpg }\end{array}$ & $\begin{array}{l}\text { http://pubs.usgs.gov/of/2012/1192/shapefiles/ } \\
\text { abumenz.zip }\end{array}$ \\
\hline
\end{tabular}

- Name-Lists the genus and species name of each taxon. In some cases where the species names have recently been revised, both a synonym and a table entry to the most recently used scientific name for that taxon are provided to facilitate locating the maps.

- Family-Lists the family name of each taxon.

- Common Name-Lists the common name of each taxon, if available (n/a, not available).

- Conservation Status-Contains the listing status for each species, according to the Smithsonian National Museum of Natural History's Flora of the Hawaiian Islands database (Wagner and others, 2005) and the U.S. Fish and Wildlife Service (2012). Categories include "Extinct," "Endangered," "Vulnerable," "Rare," and "Apparently Secure" (see http://botany.si.edu/pacificislandbiodiversity/hawaiianflora/1999Assessment.html for discussion of conservation status categories; see also, Wagner and others, 1999).

- Native Status - Lists the natural distribution of the species. Categories include "Endemic" to the Hawaiian Islands and "Indigenous" to the Hawaiian Islands but also found naturally elsewhere.

- Map Type-Lists the type of range map that has been generated by this study. Categories include "Model," which means that the range map shows the potential range of a species (either estimated, possible, or both) modeled by this study; "Point," which means that the approximate location of the only known locality of a species is shown on the range map as a point locality; and "Descriptive," which means that the "potential area of historic collections" of an extinct species has been shown on the range map.

- DOWNLOAD JPG FILES - Contains a link to download the JPG file of the range map for each species.

- DOWNLOAD GIS FILES (shapefiles, in zip format)-Contains a link to download the shapefile for the range map of each mappable species. The shapefiles are projected in UTM Zone 4N coordinates using NAD83 datum. 